\title{
THE MASTERPIECES OF
}

N

40.1

C75M4

NMAA
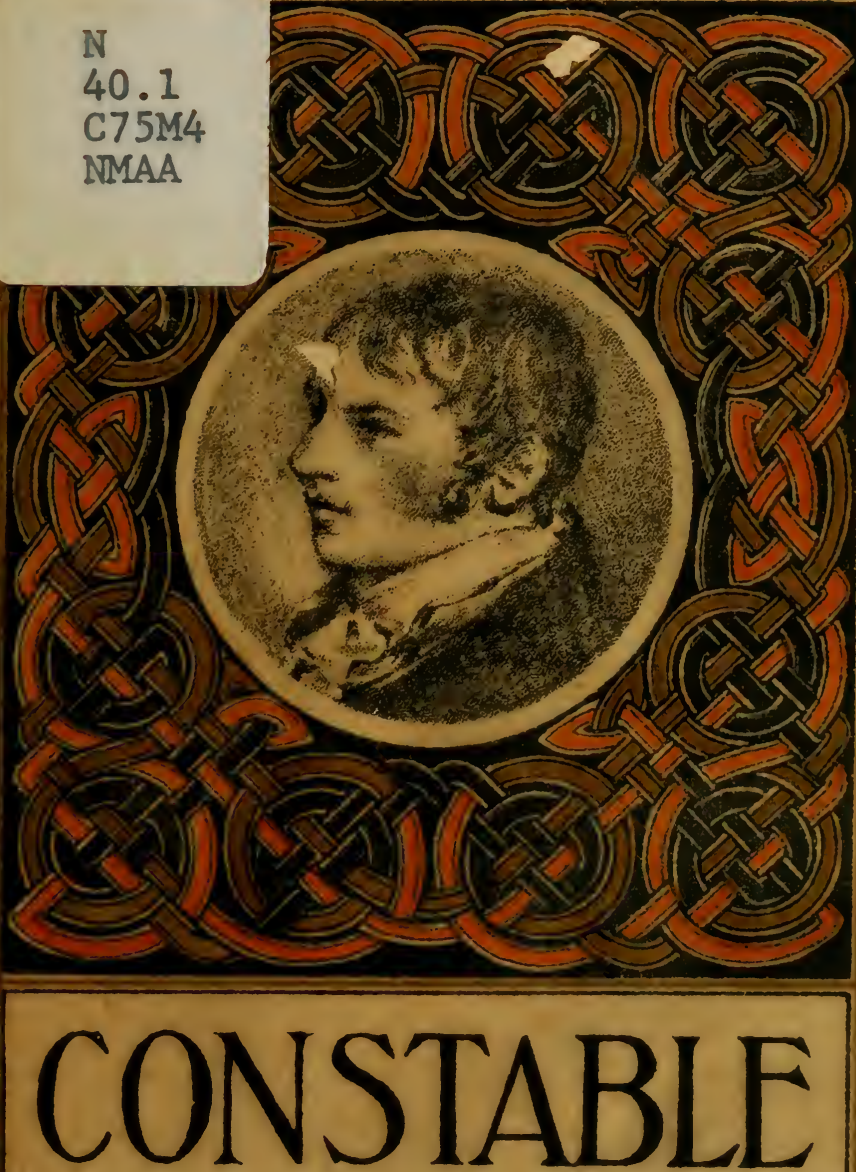





\section{The Masterpieces of Constable}

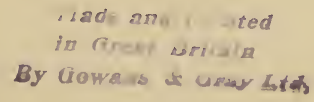

R. MACLEHOSE AND CO. LTD., PRINTERS, GLASGOW

BI.UCKS BY HISLOP AND DAY, EDINBURGH, AND F. HANFSTAENGL, MUNICH

PAIER BY ALEX. COIVAN AND SONS, LTD,, EDINBURGH 


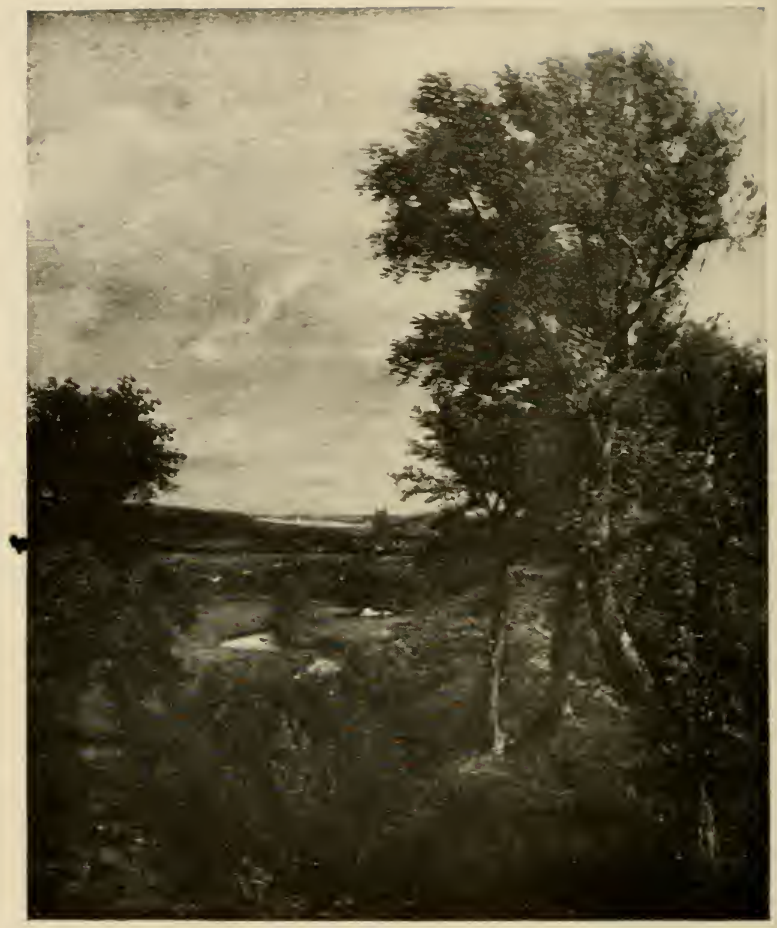

DELHAM VAI.F:

[1802] I.A V'Alitík DE DiEHHAM DAS TAl, VON DEUHAM

(I'ictoria and Albert Mluseum, South Kinsinstin) Gowans \& Gray, I.til., Plinto. 


\section{THE \\ MASTERPIECES \\ OF \\ CONSTABLE \\ (1776-1837)}

Sixty reproductions of photogrephs from the original paintingsh

$\frac{7}{8}$ affording examples of the different characteristics

of the Artist's work

\section{NoV sc 1985}

NEW YORK

FREDERICK A. STOKES COMPANY

Publishers 


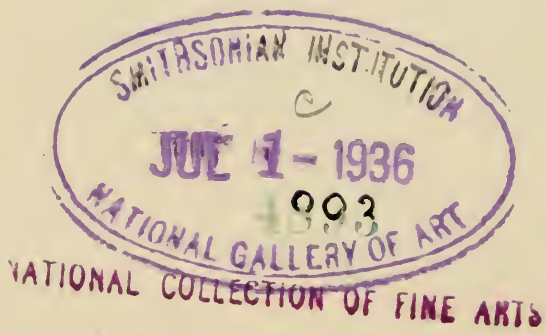




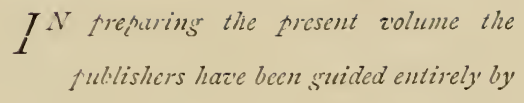
1/r. C. J. Holmes's admirable monograph on the artist. They hav'e only inserted fictures which afpear in his list, and they hure arranged them chronologically, aftending the dates as he has given them. They havere also to express their gratitude to .11r. Holmes for permission to make use of a photograph which appeared in his book, and to those frizute owners wiho haz'e permitted the reproduction of certain pictures.

\section{tanzis}

(ii) 26 

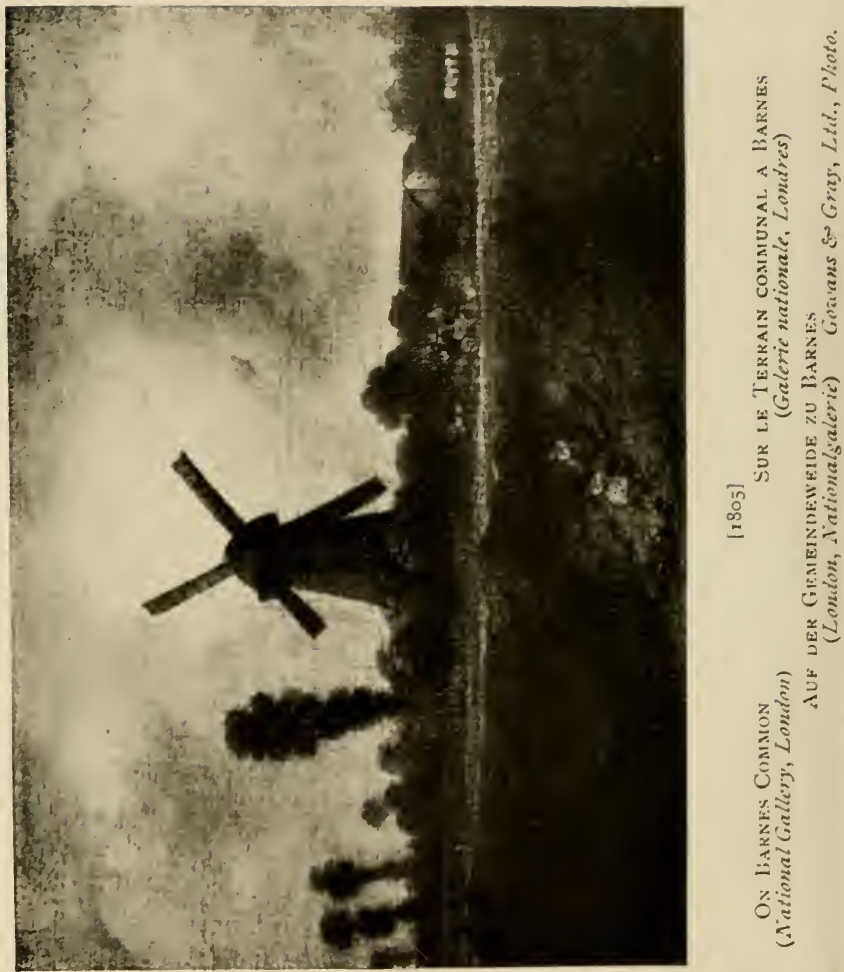

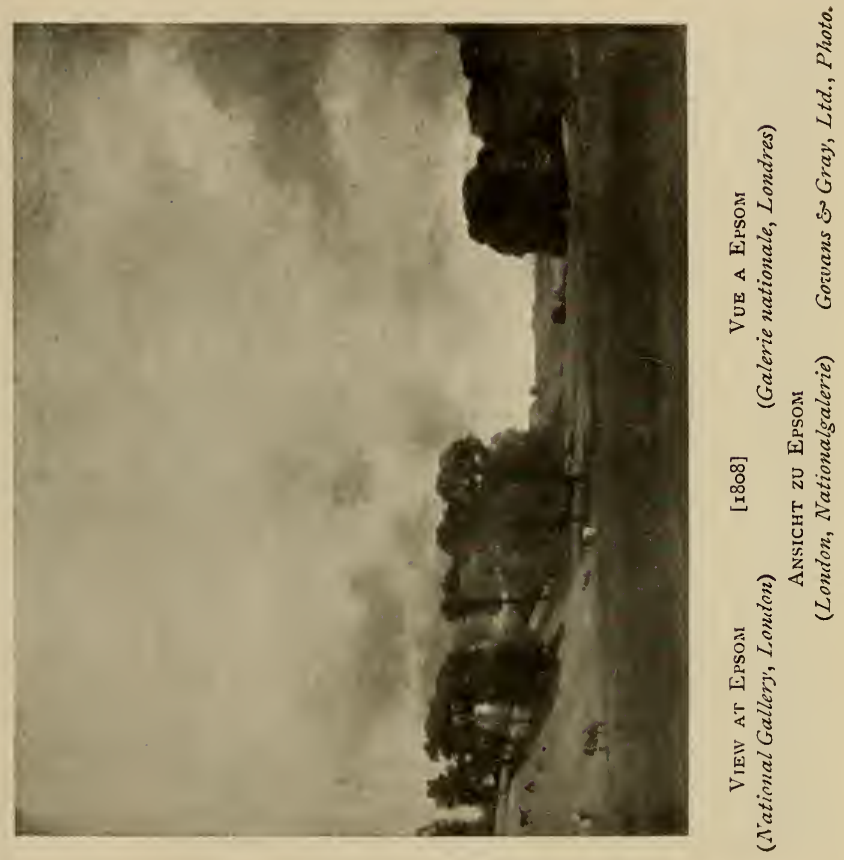

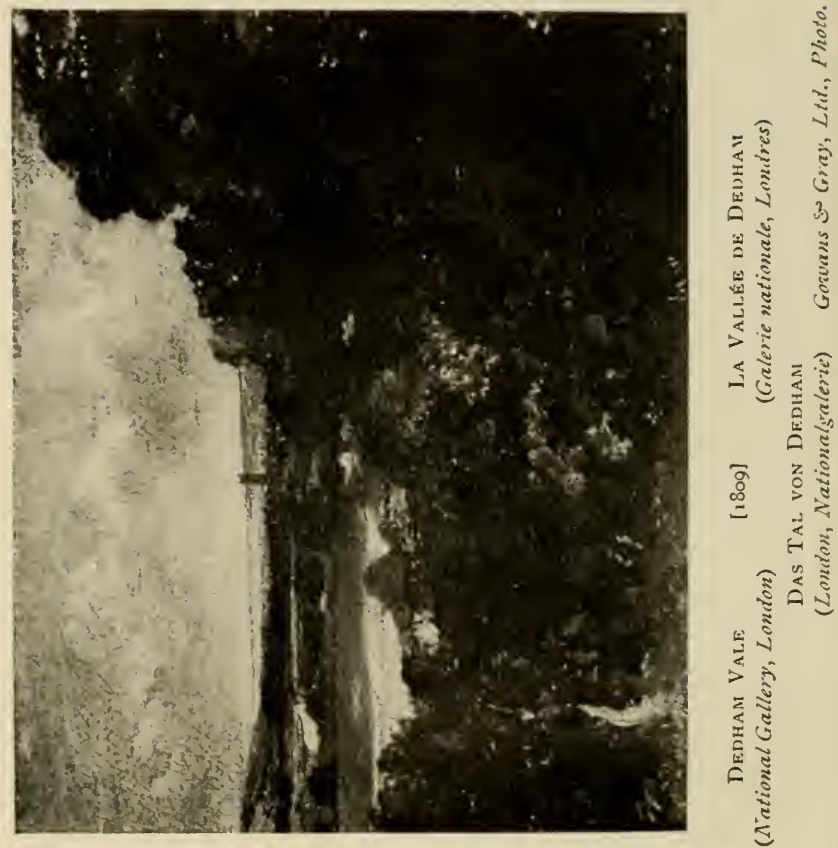


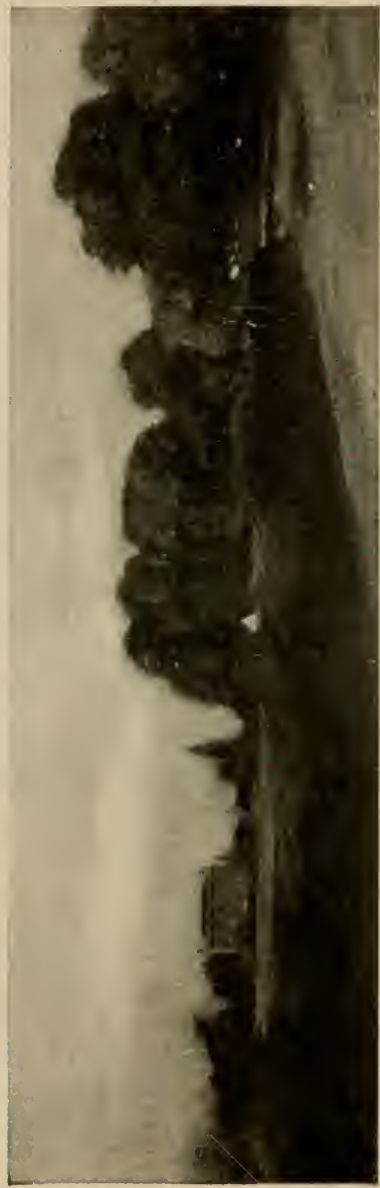

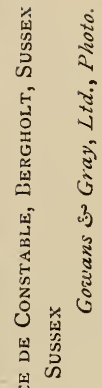

选

दो

z

볼 워

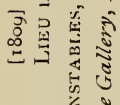

命

है

옴

บ

난

热 


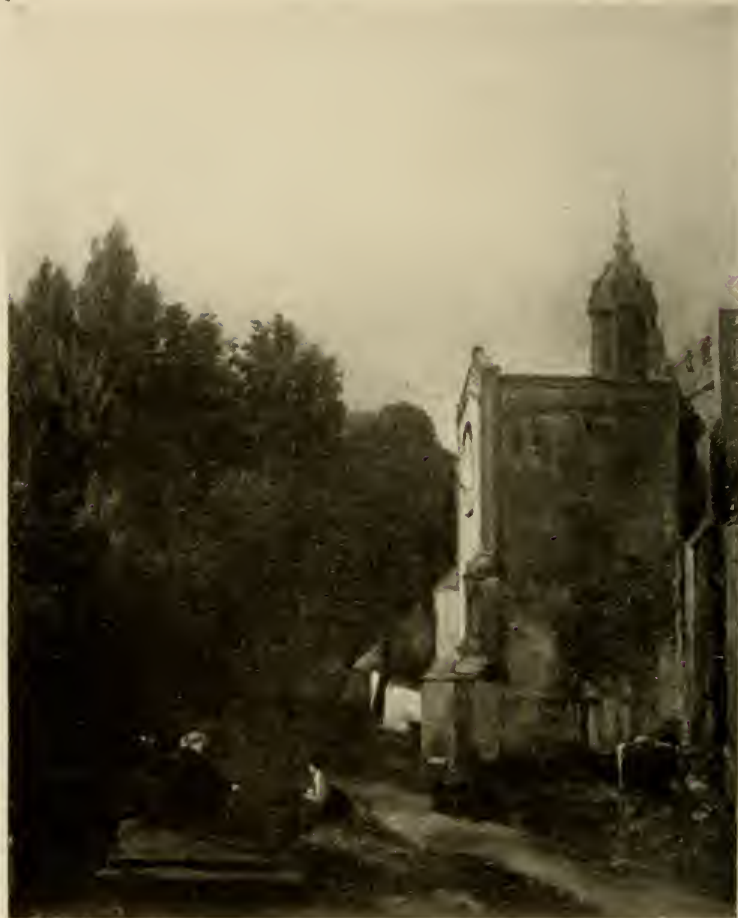

[18II]

Church Porch, Bergholt, Portique d'Églisf, Berghoit, SusSFX Sussr X

Kikchentokhalle in Beirghot.t, Sussex

(Tate Gallery, London)

Gowans \& Gray, Ltd., Ploto. 


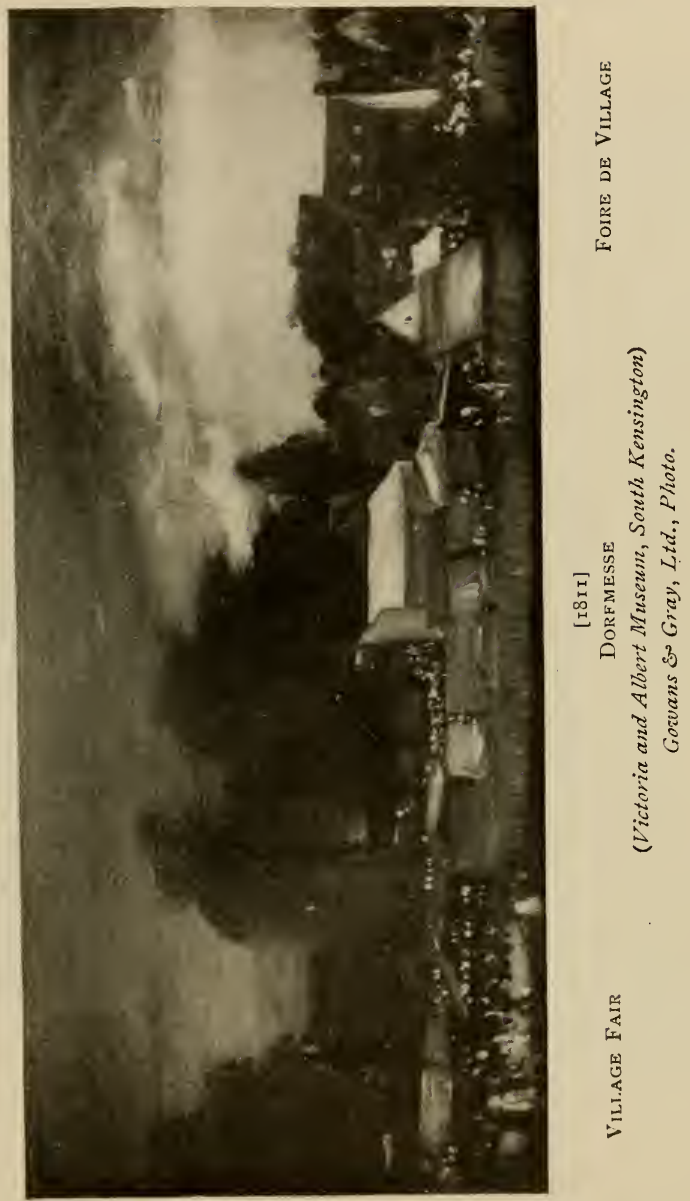




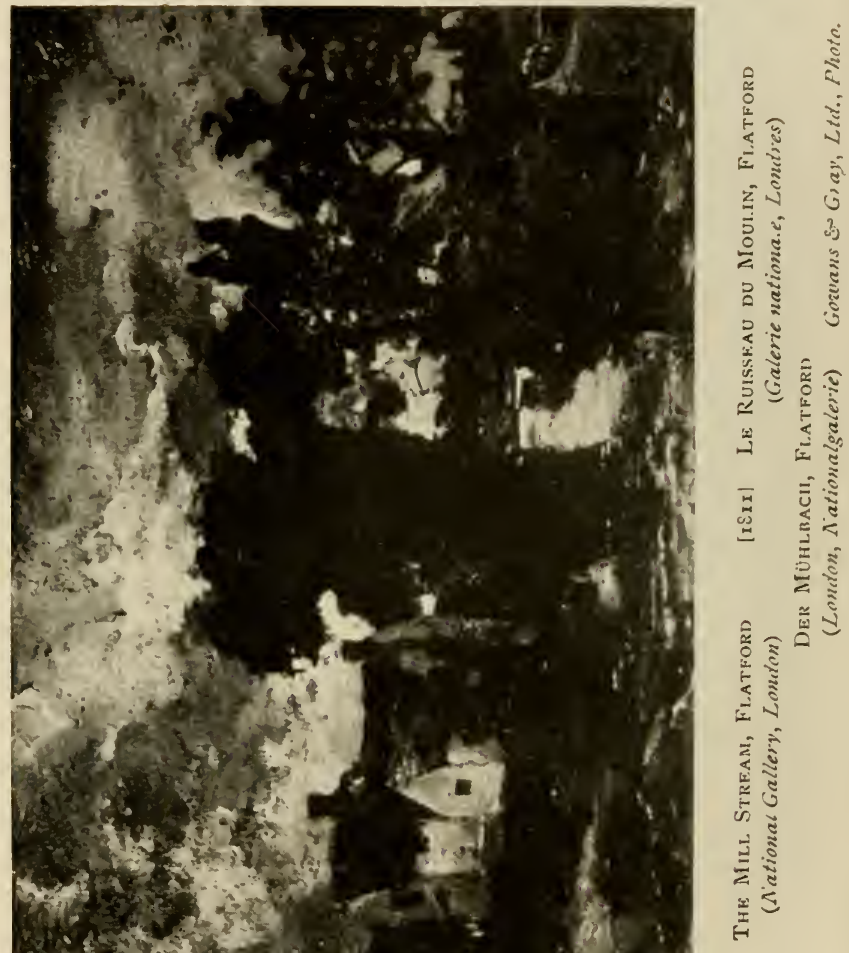




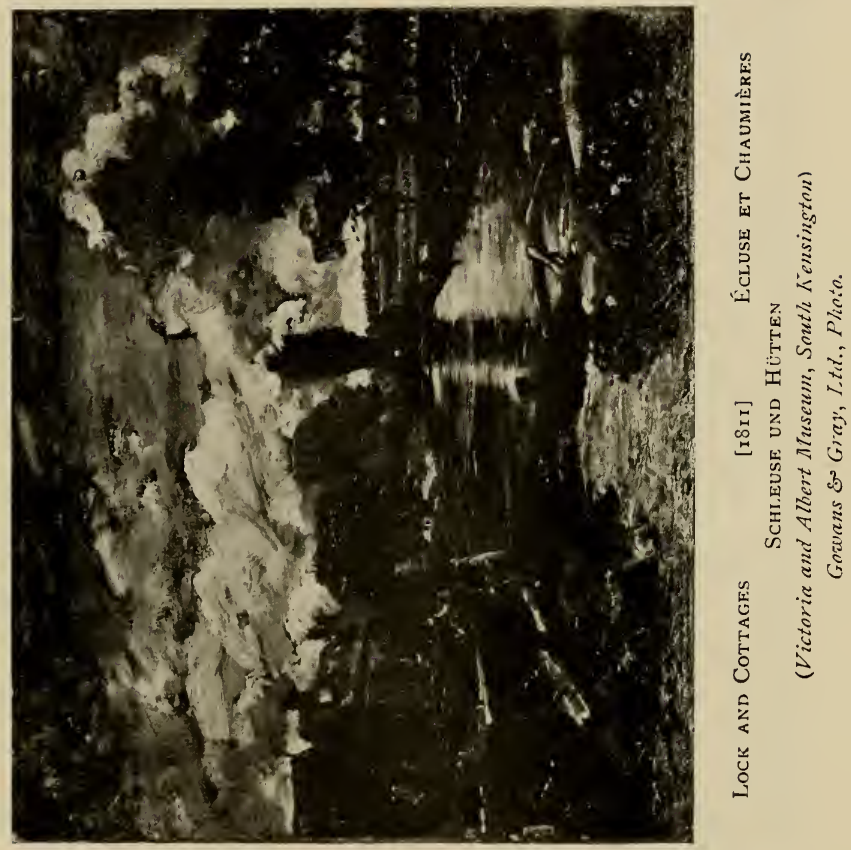



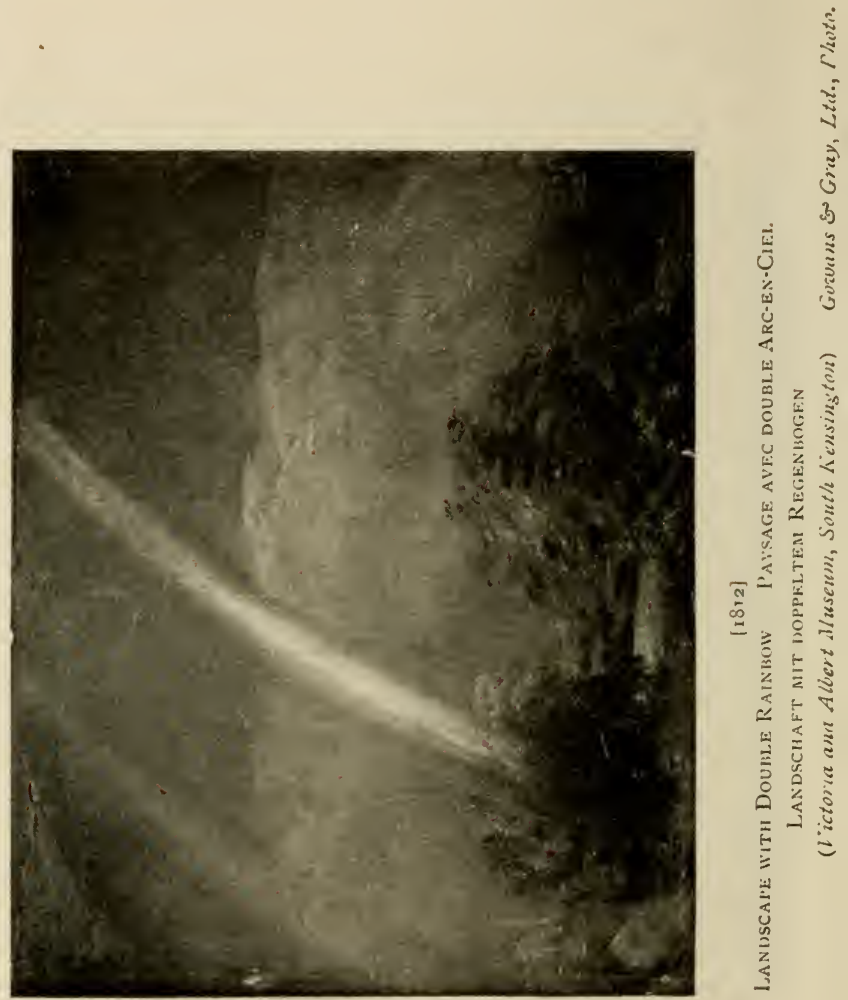


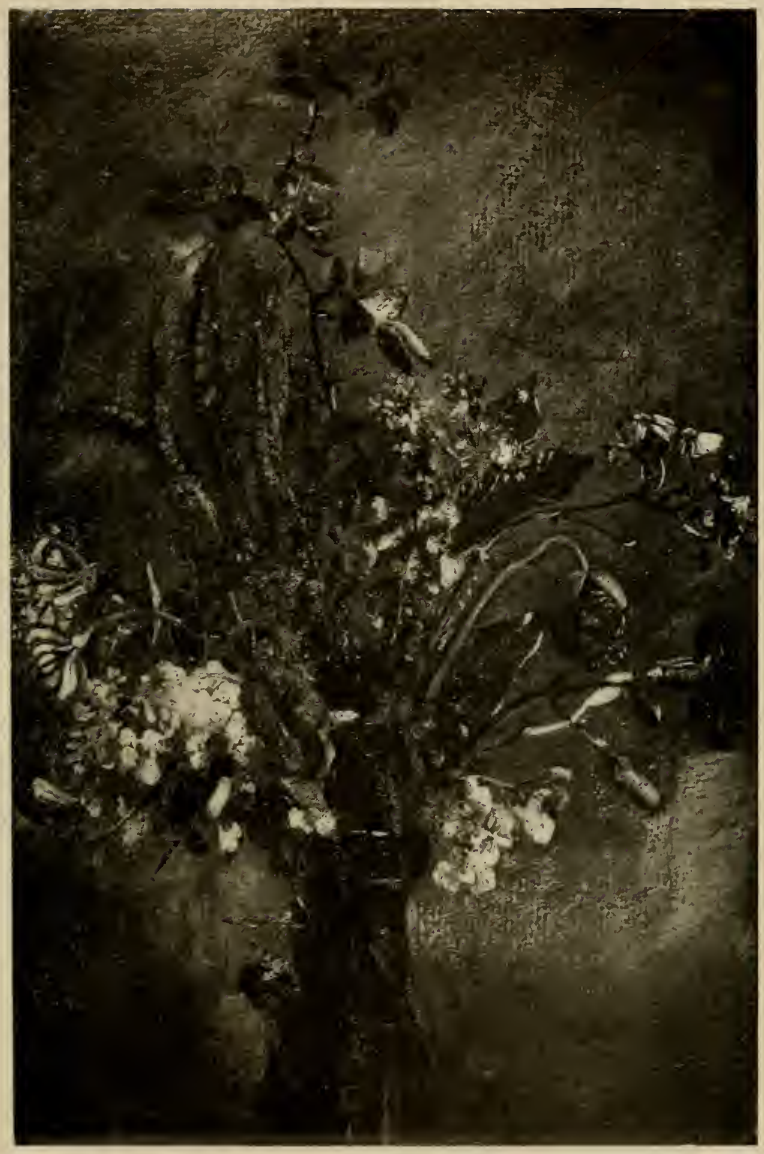

[1814]

Siuny of Flowers Blumenstudie Étude ne Fieurs

(Victoria and Albert Museum, South Kensington)

Gowans \& Gray, Ltd., Photo. 


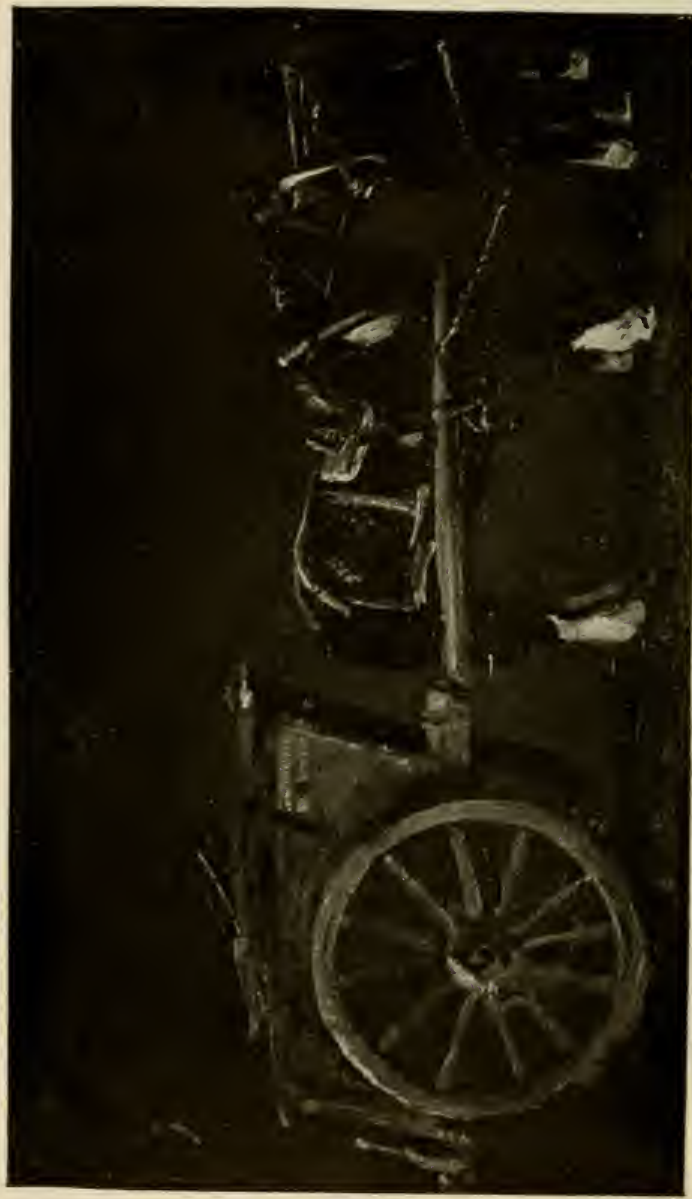

3

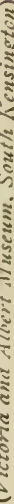

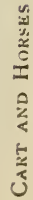



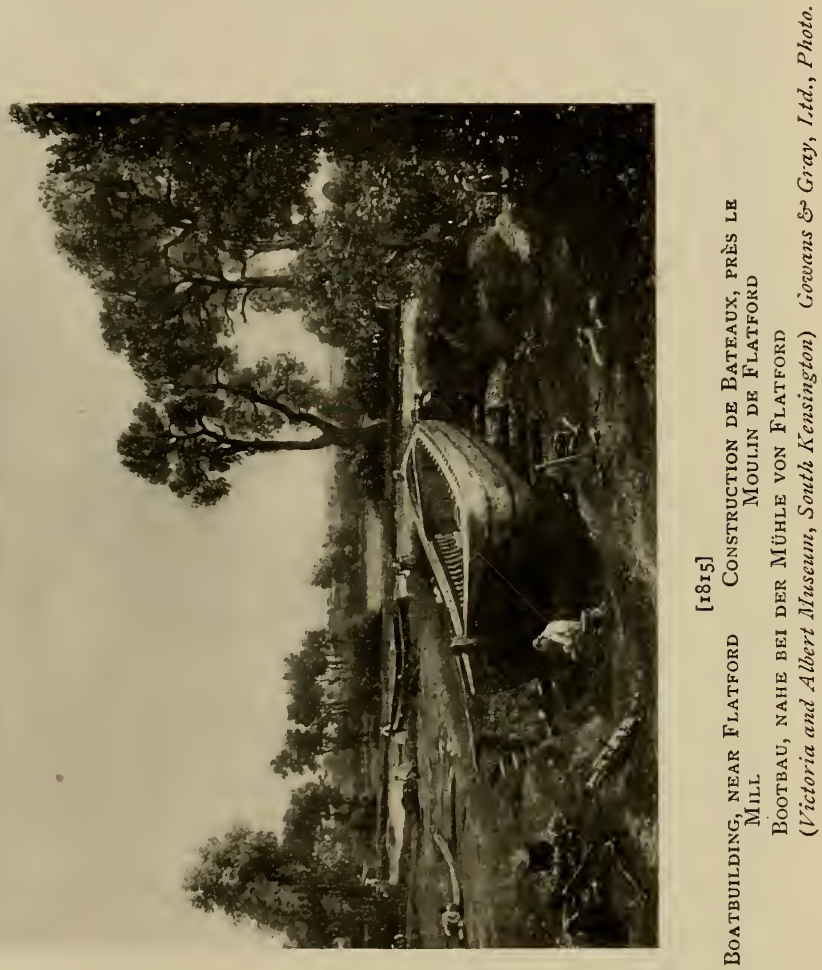


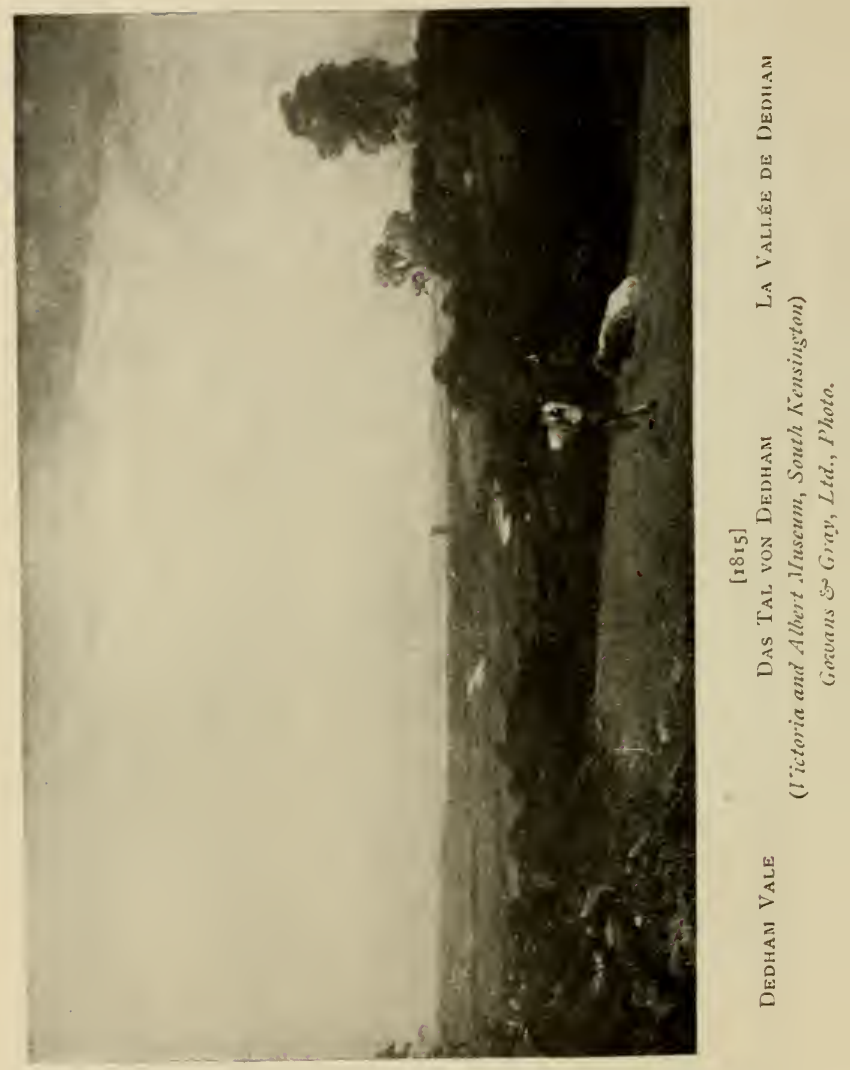




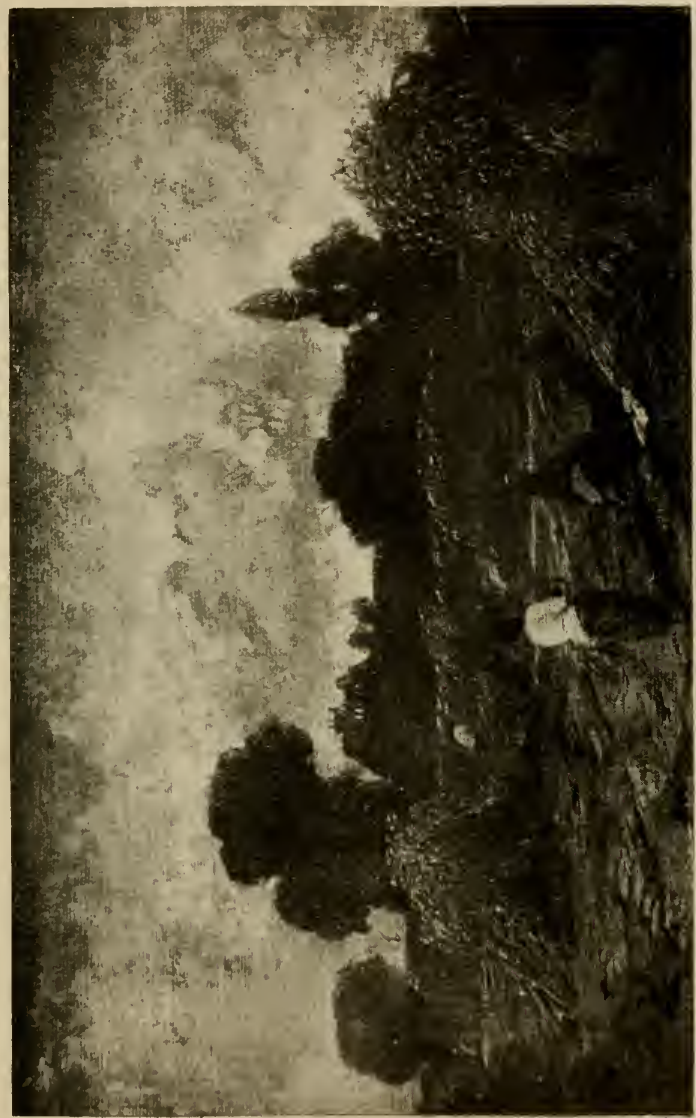



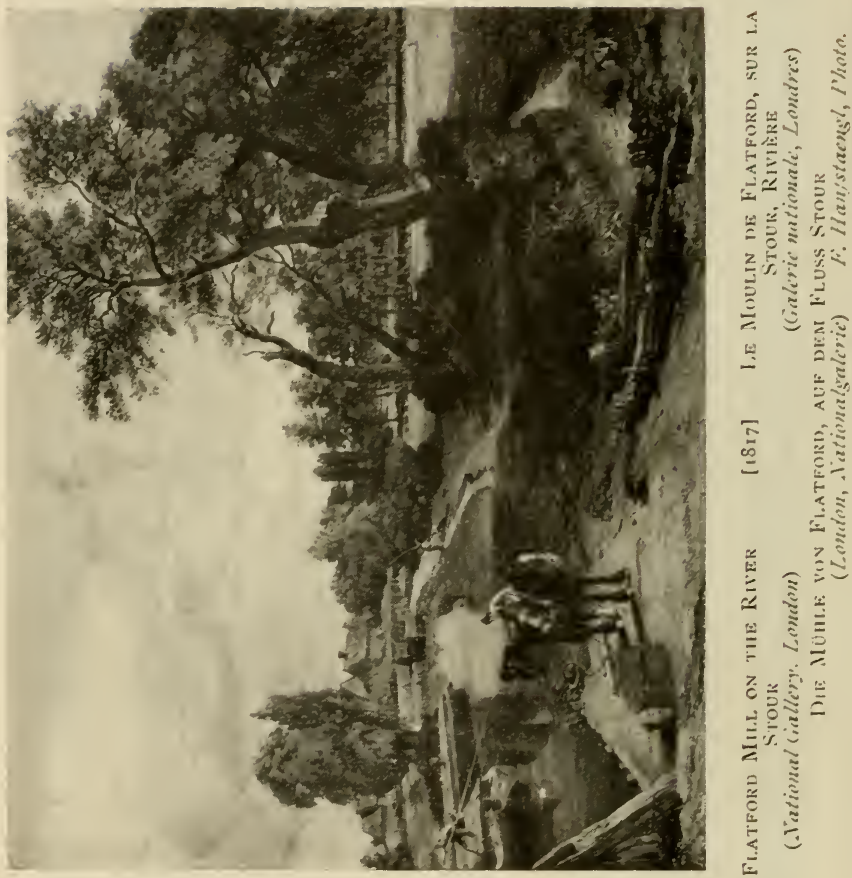


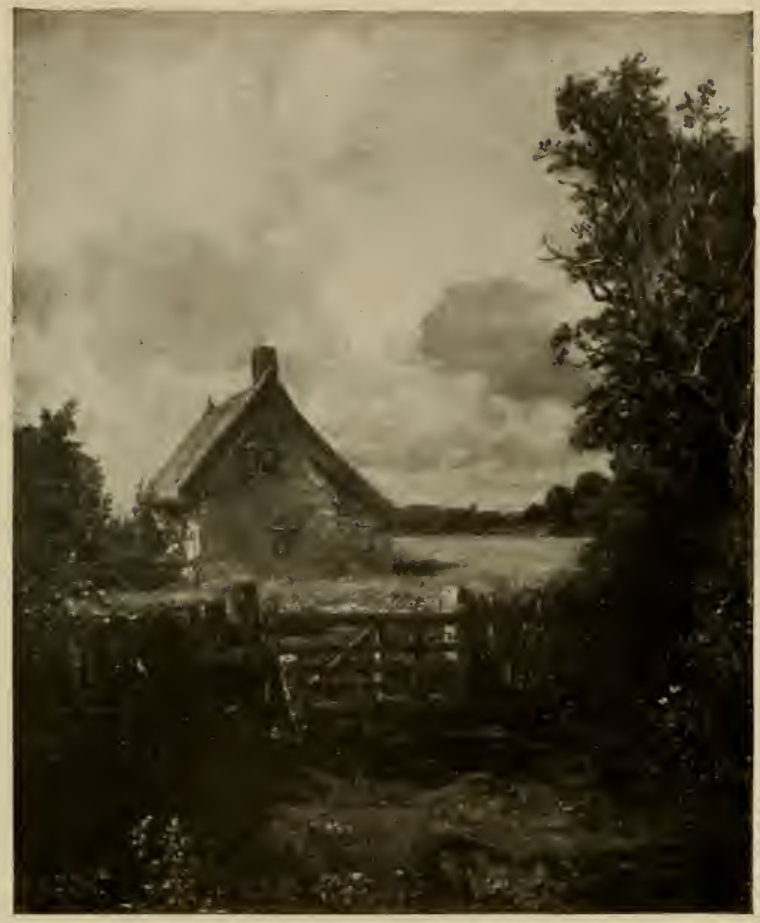

\section{[1818]}

The Cottage in the CoRnfield

La Chaumière dans le Champ ()E BLE

DIE HÜTTE IM KORNFEI,

(Victoria and Allert Minscum, South Liensins'tun)

Gowans \& Gray, Ltd., I'hoto. 


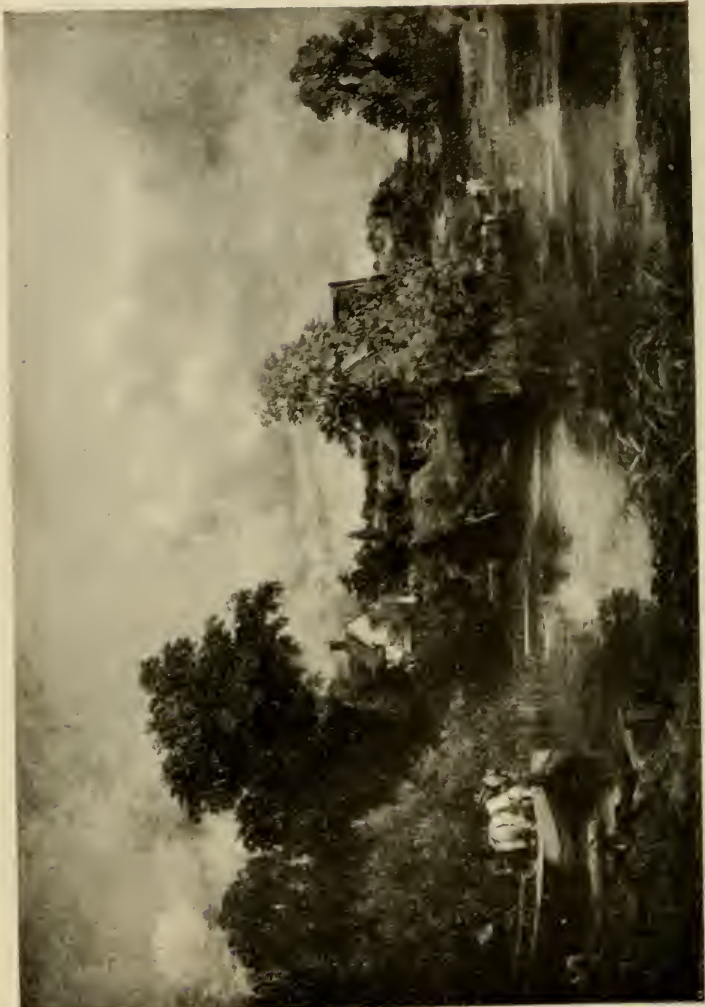

致

1)

正

ㄴ)

5. $\div$

些:

它

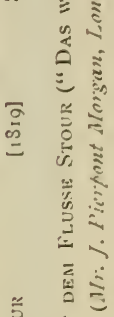

它我乐

닌

$-2$

类竞

7

미:

这

U. 

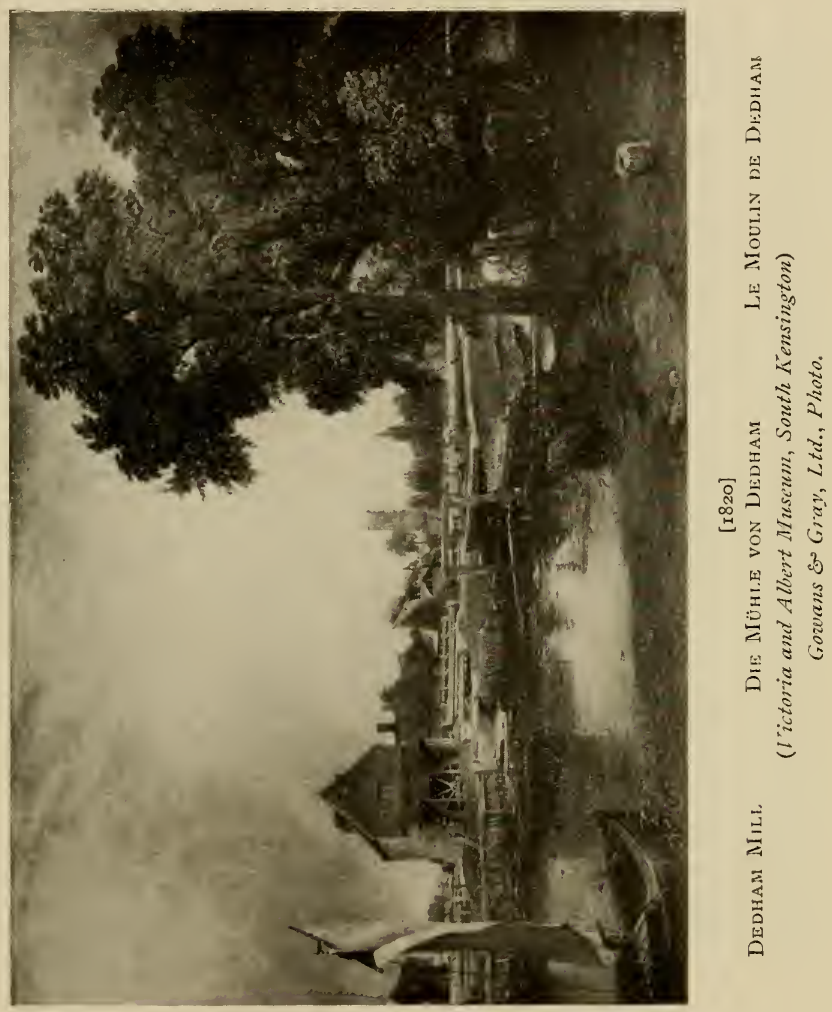

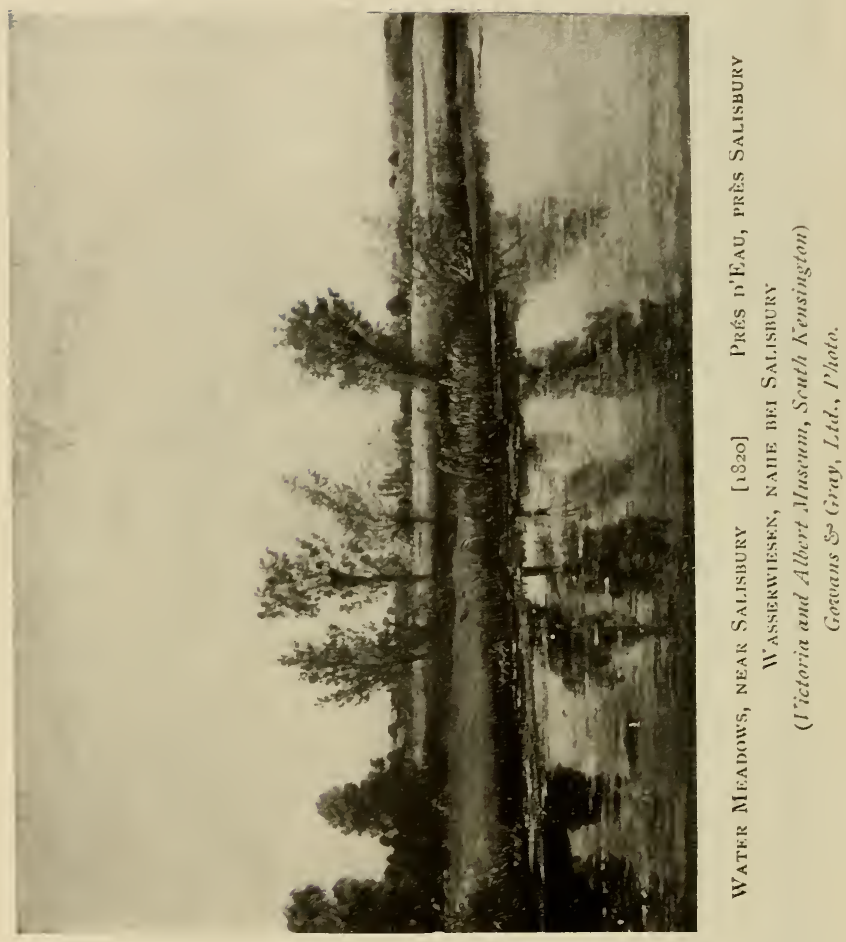


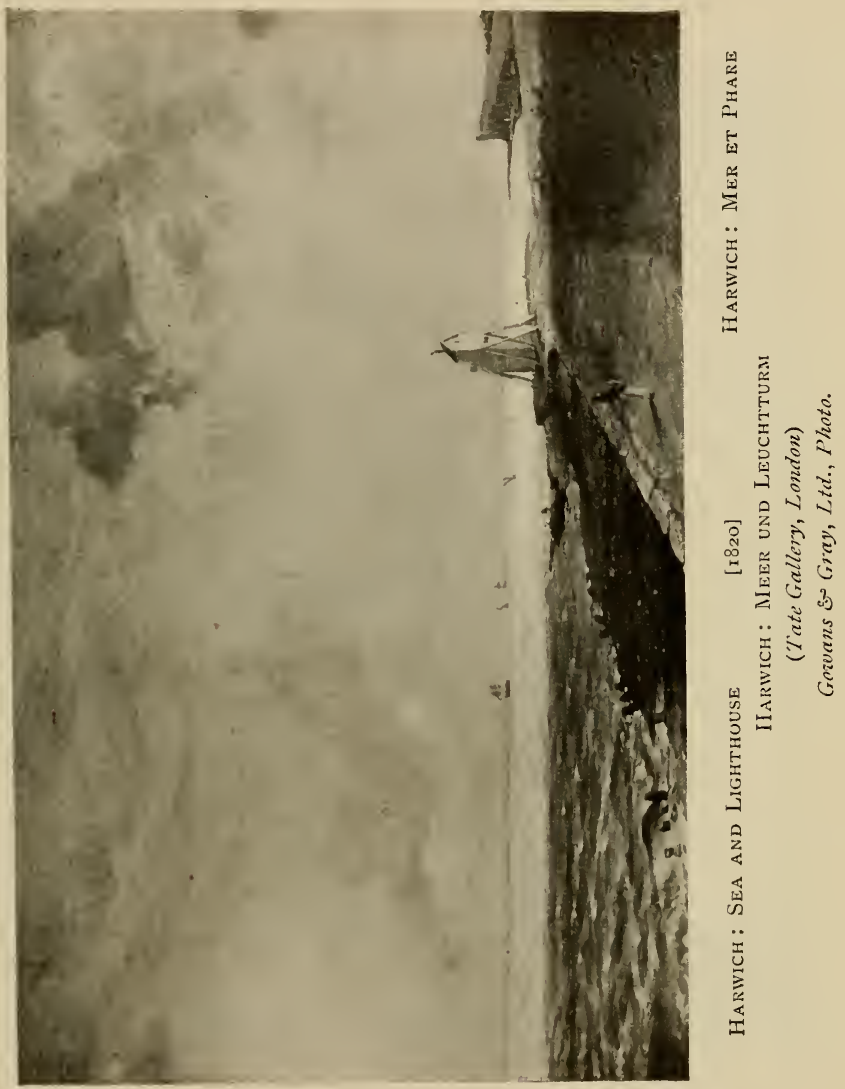



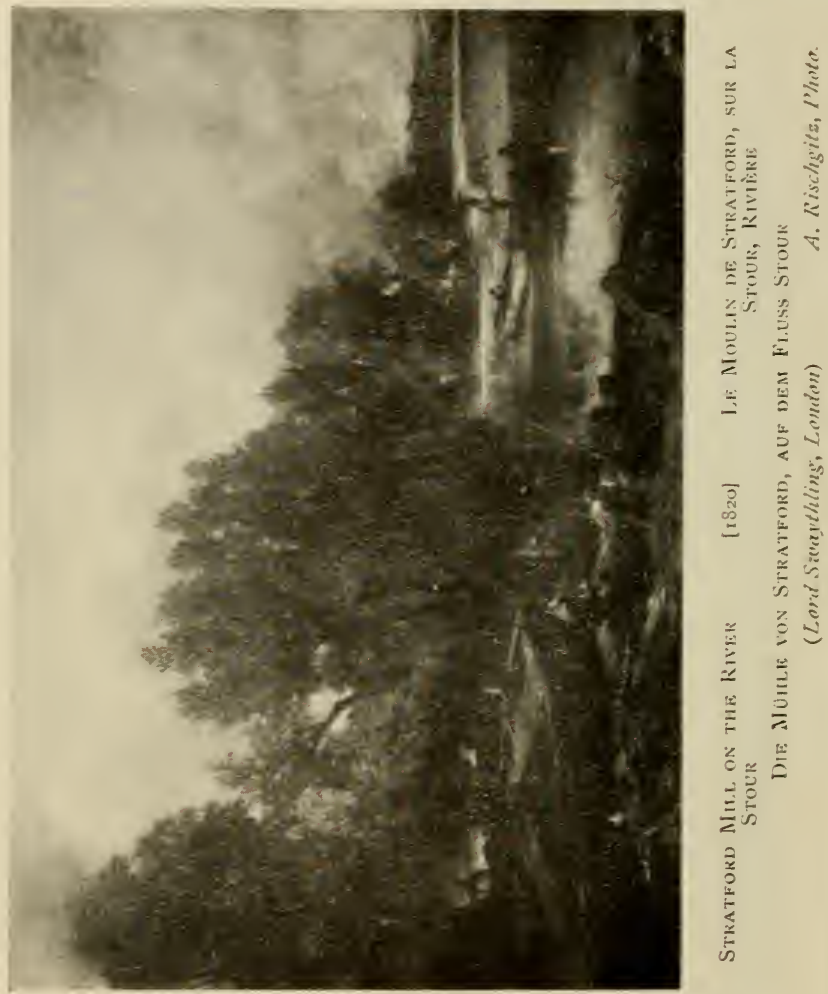


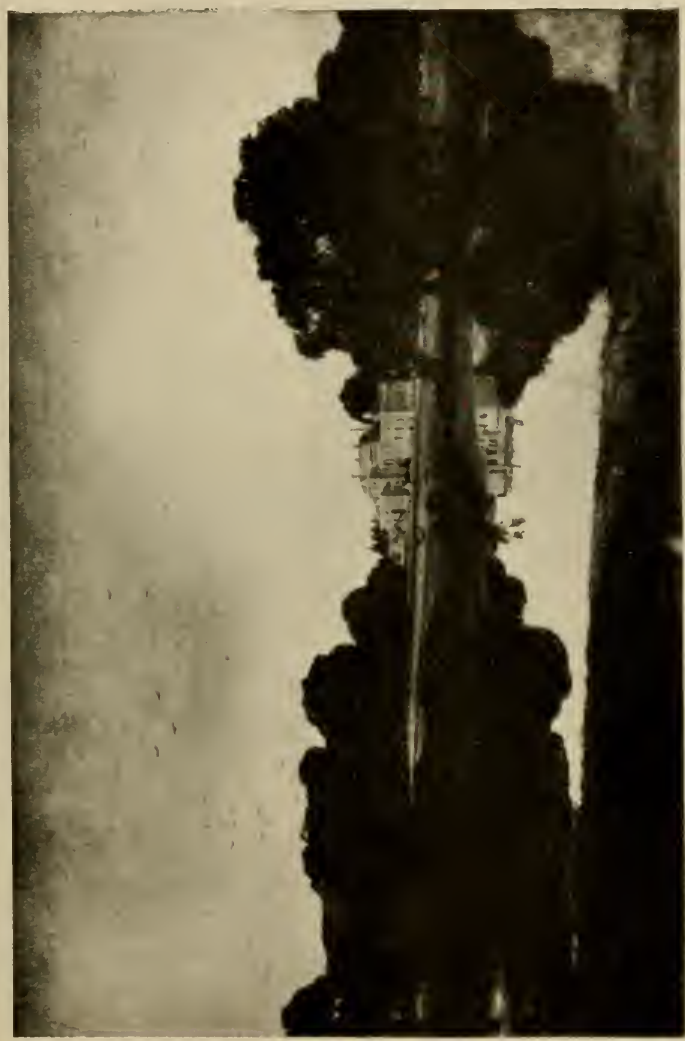

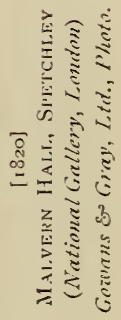




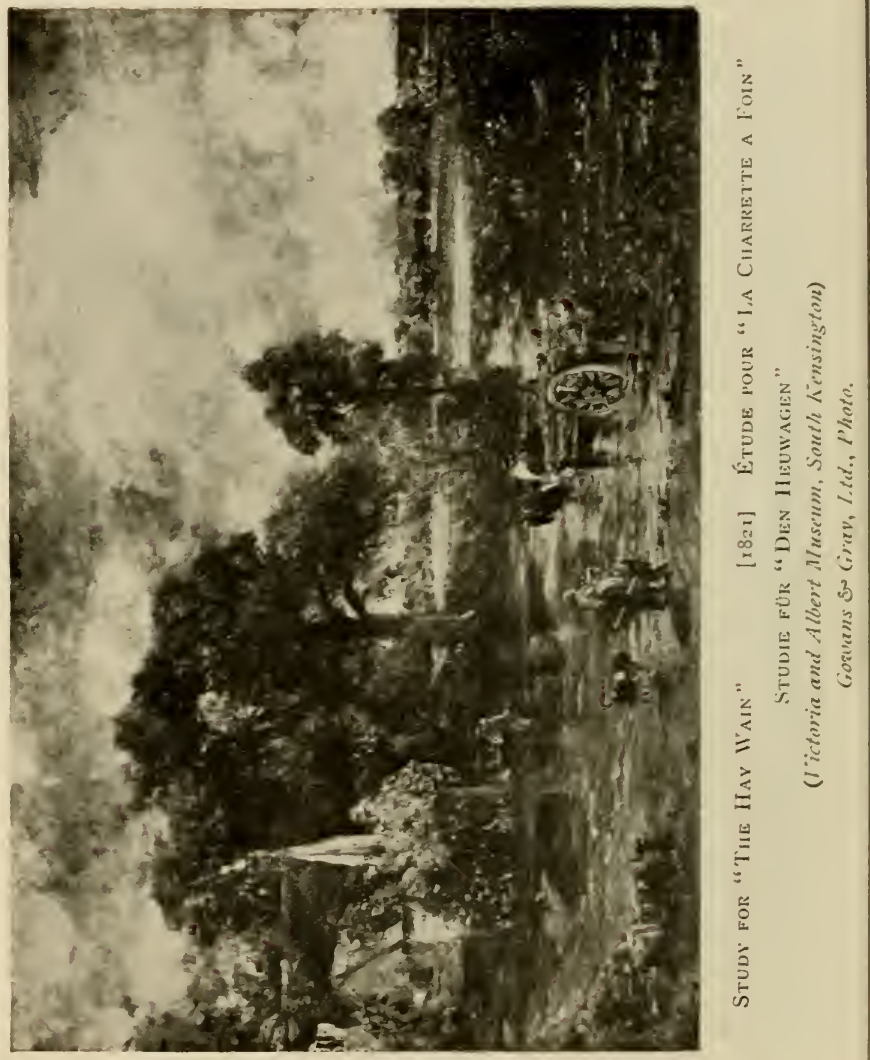




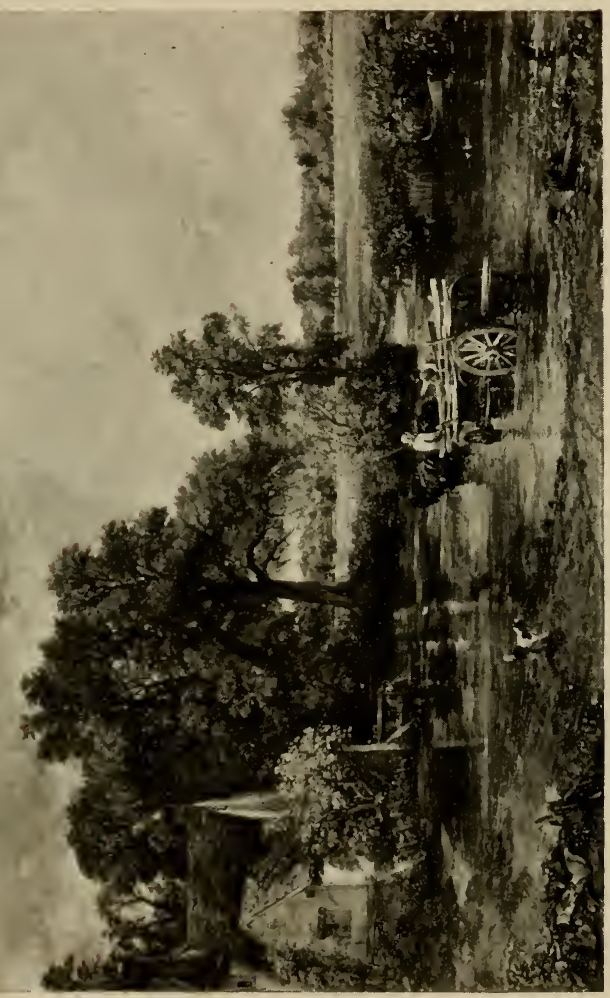

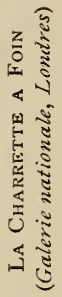

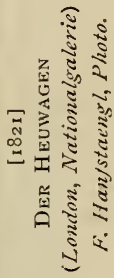

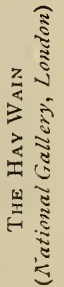




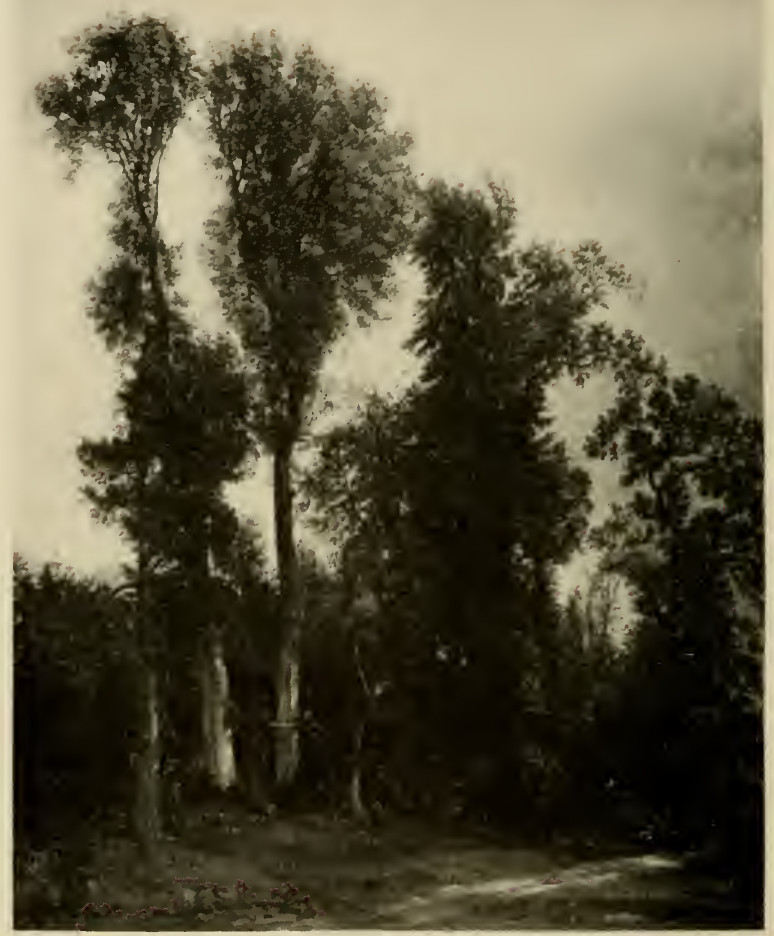

TKI:ES NHAR HANPJEAD Cilurch

$[1821]$

BÄUME NAIE BEI DER KIRCHE ZU HAMISTEAI)

(Victoria and Albert M/uscum, South Kensington)

Cimans \& Ciray, I.tal., l'hoto, 


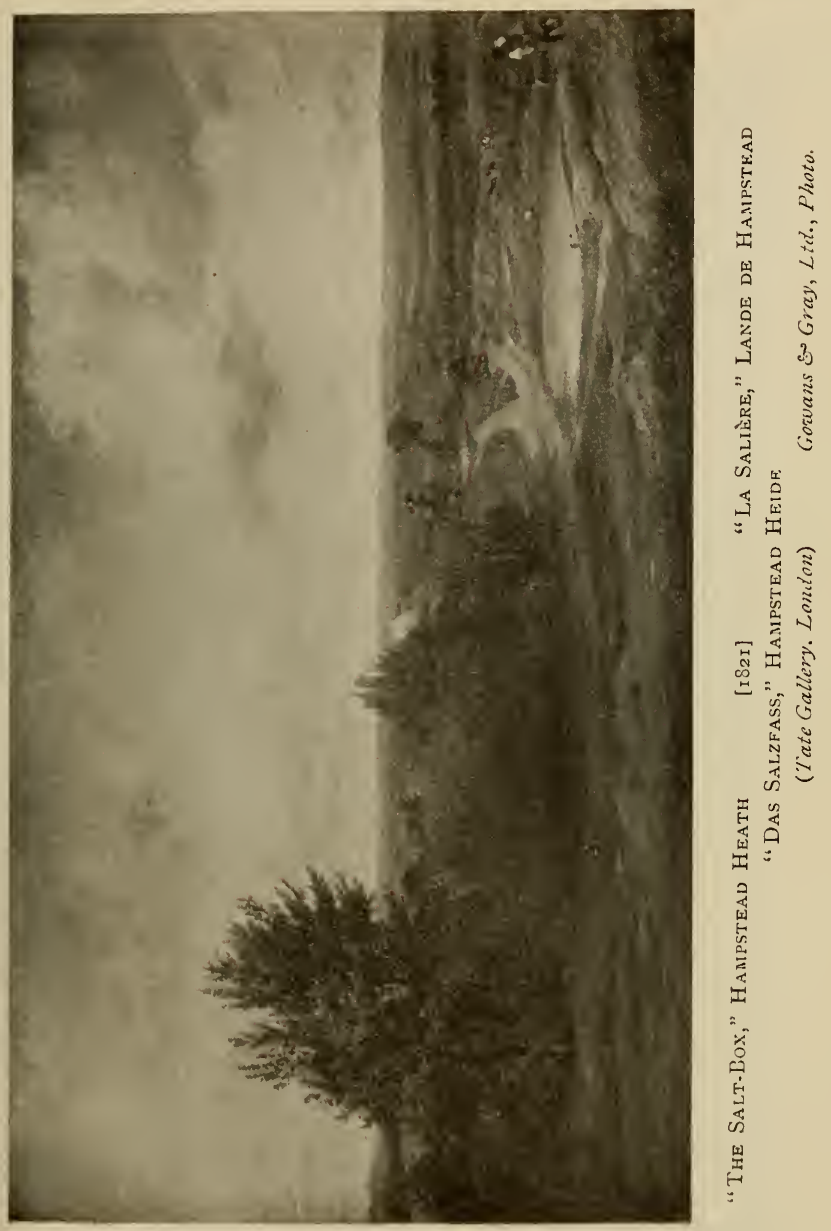




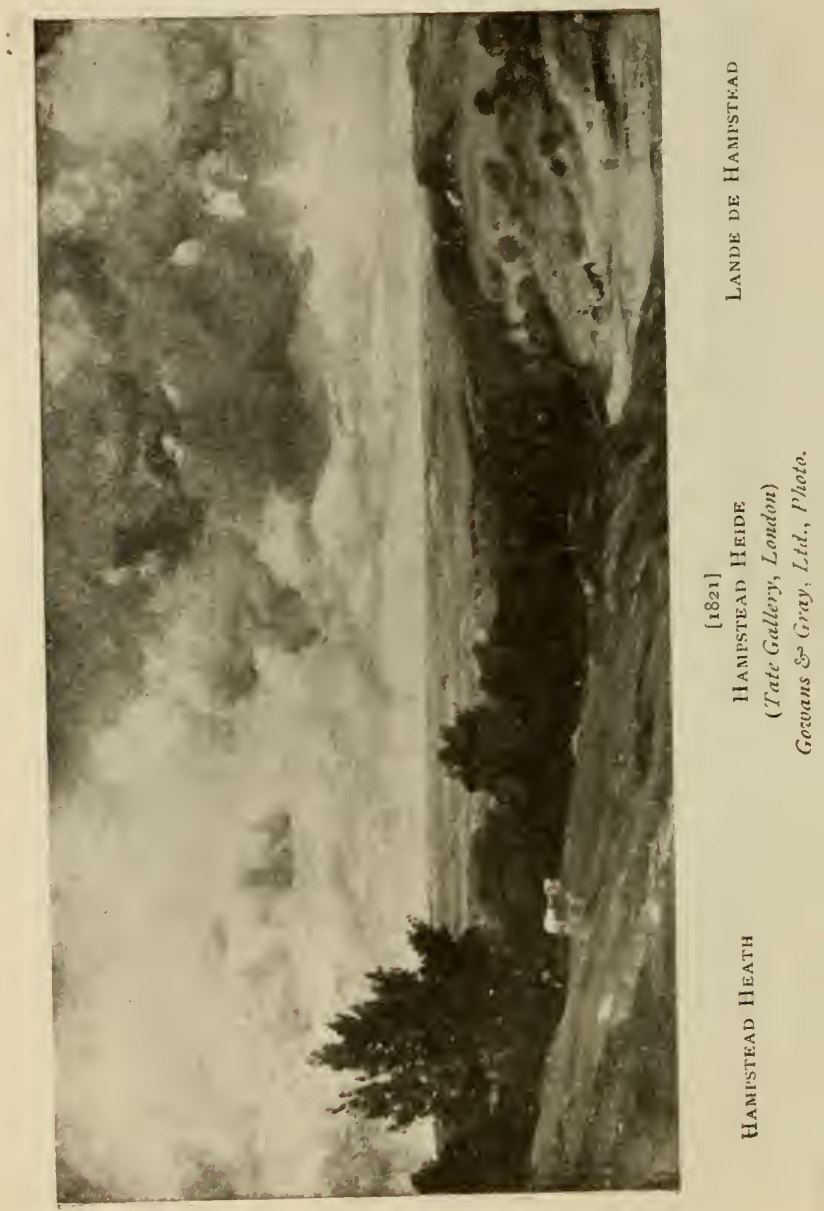




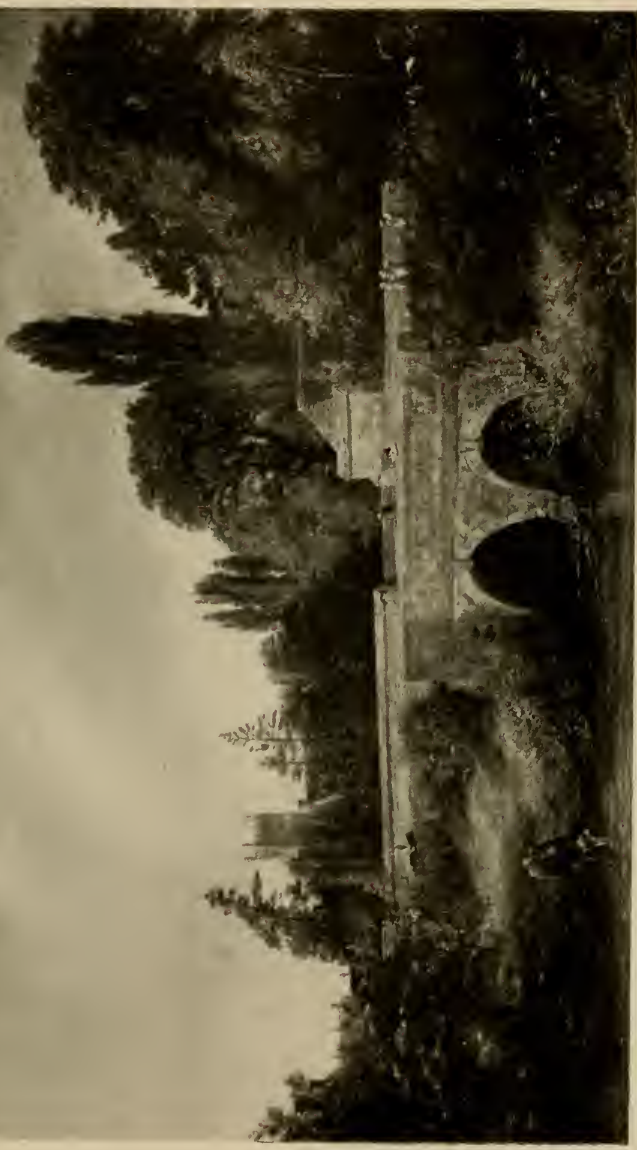

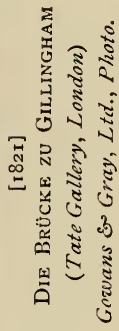

造 


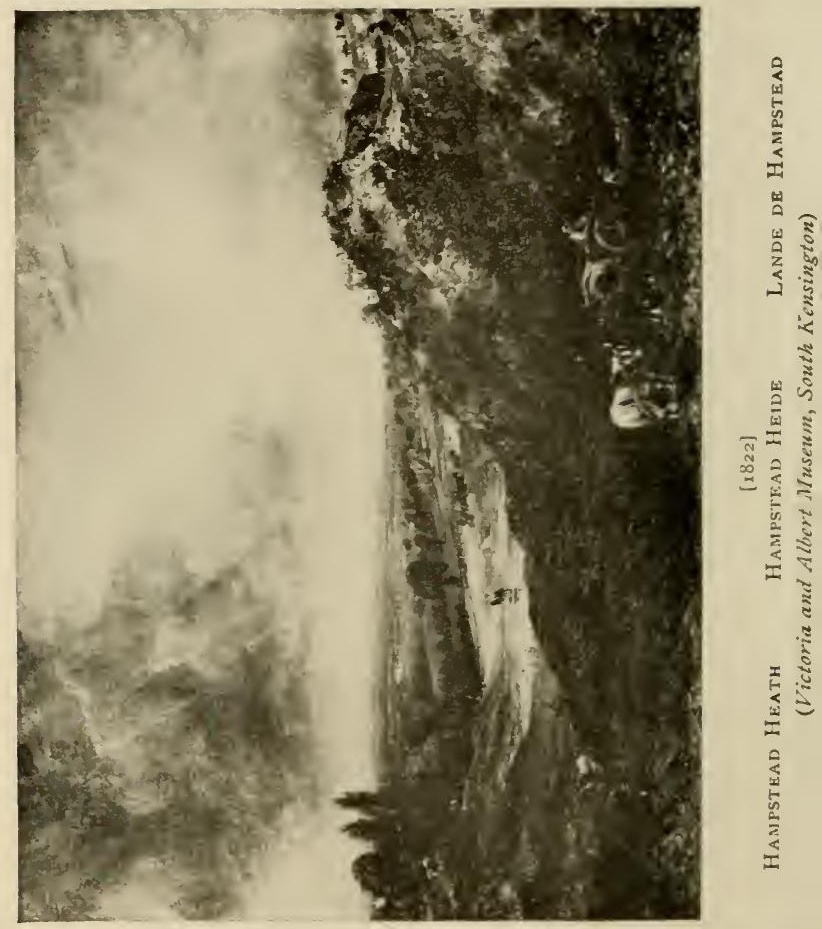




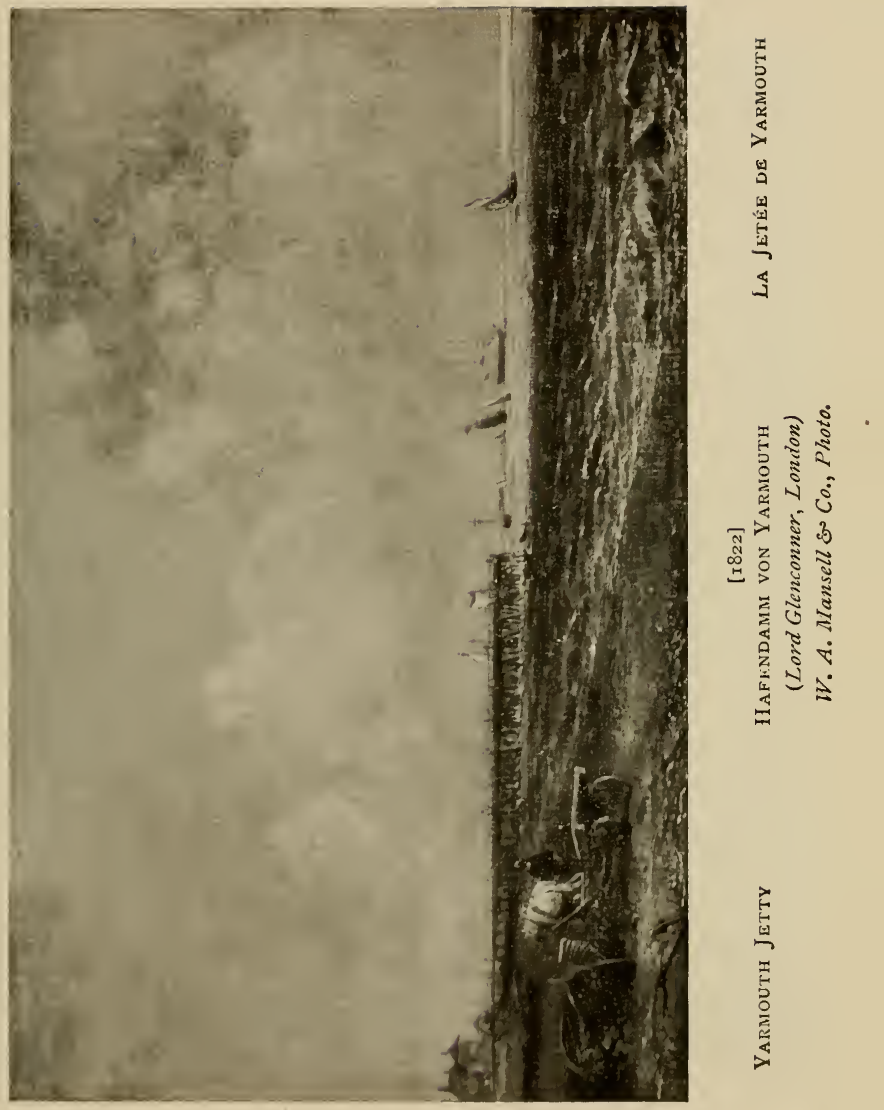




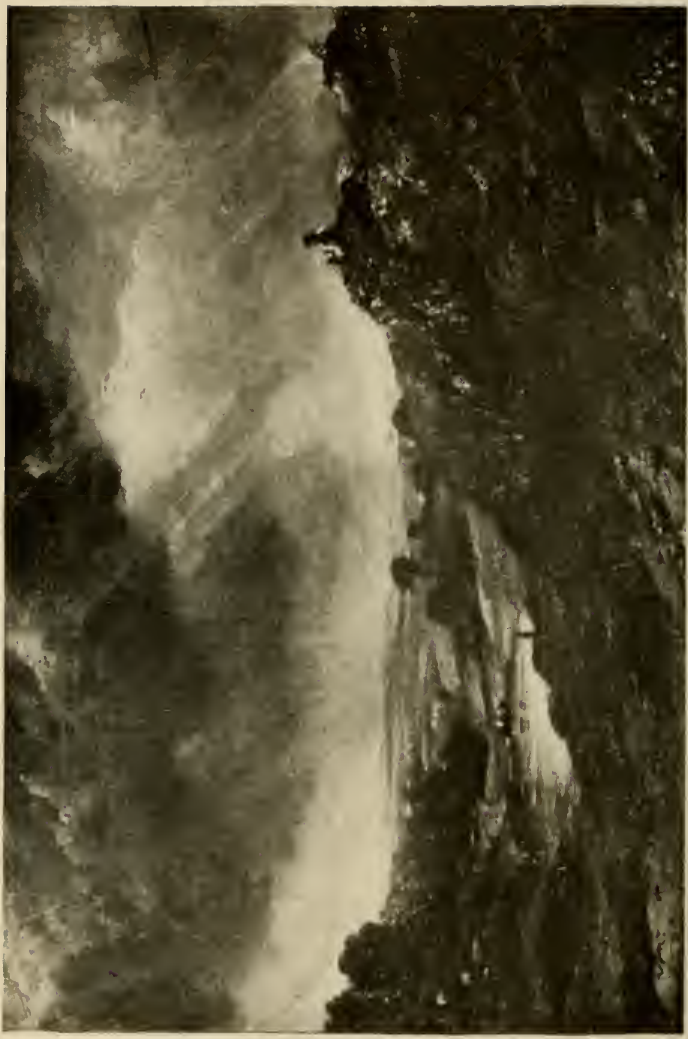

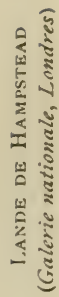

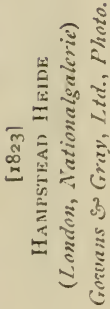

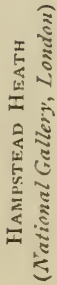




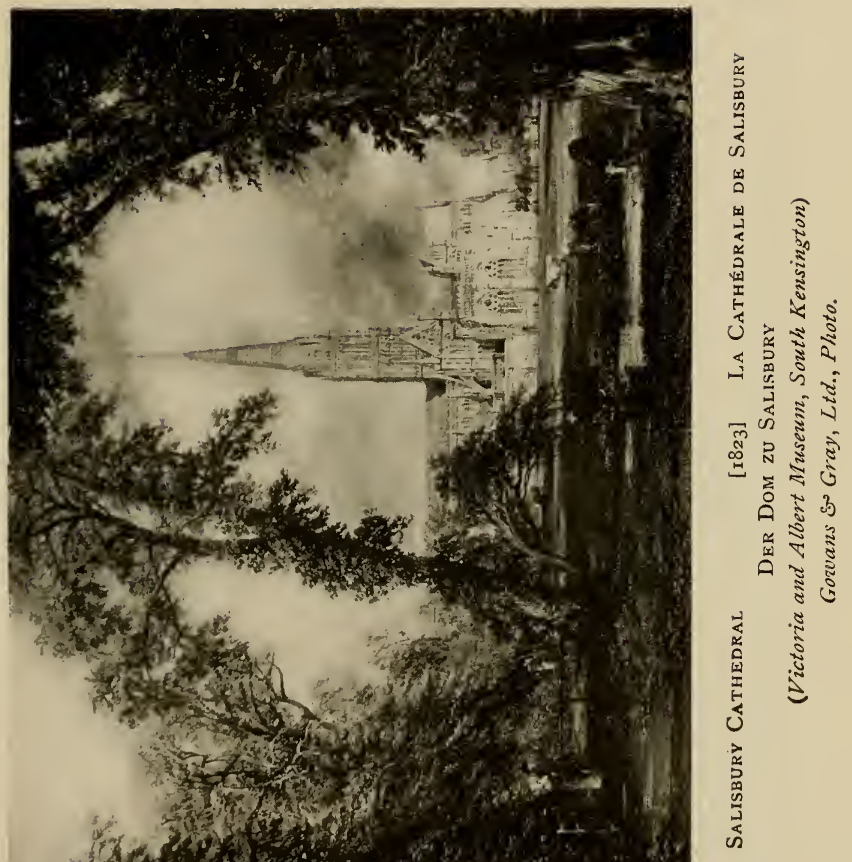




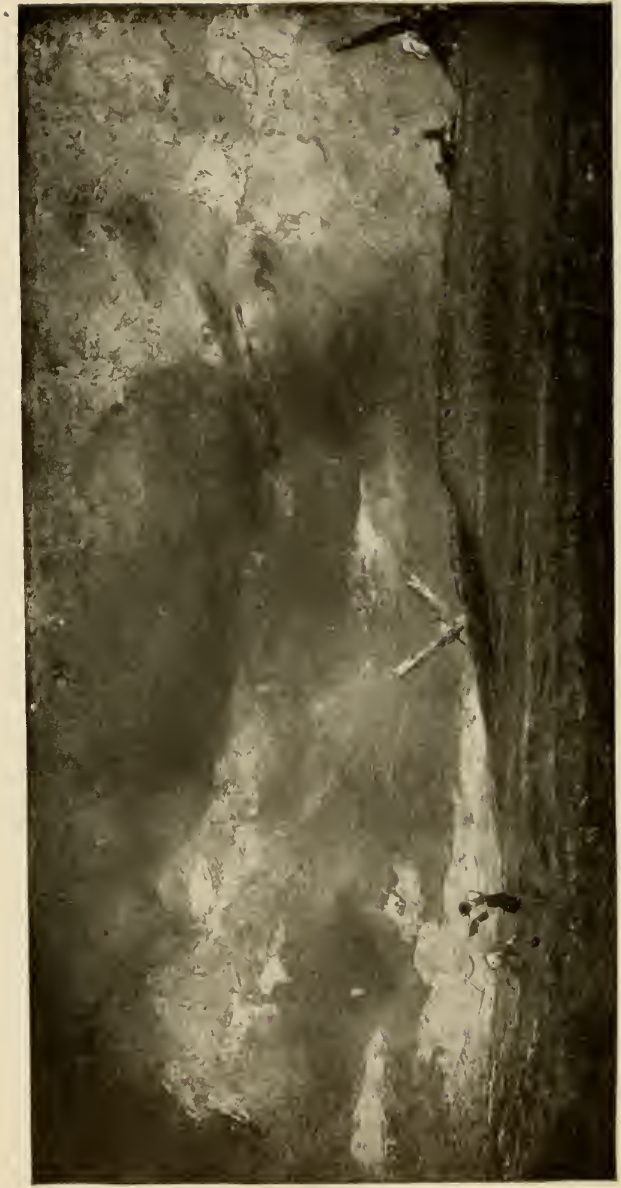

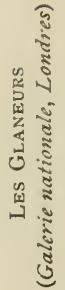

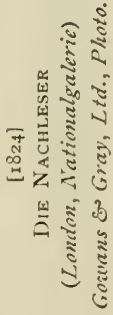

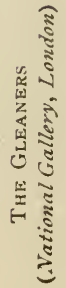



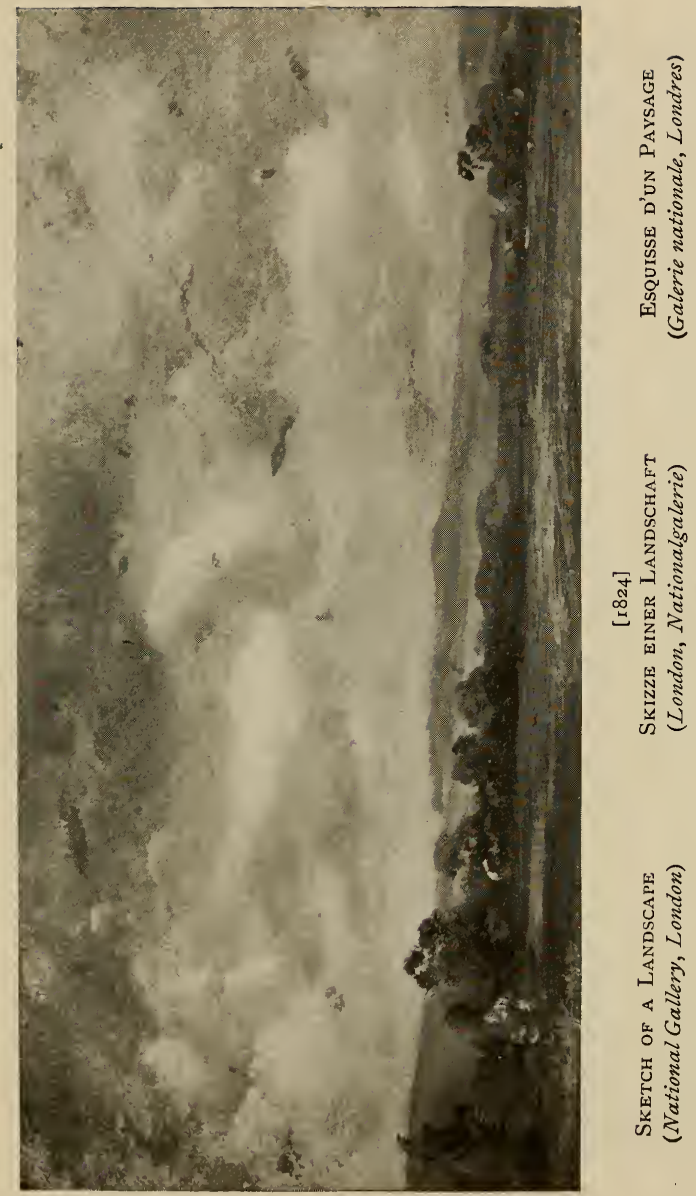

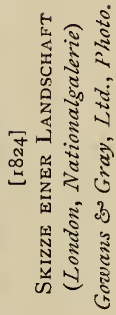

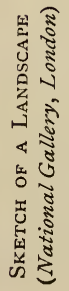



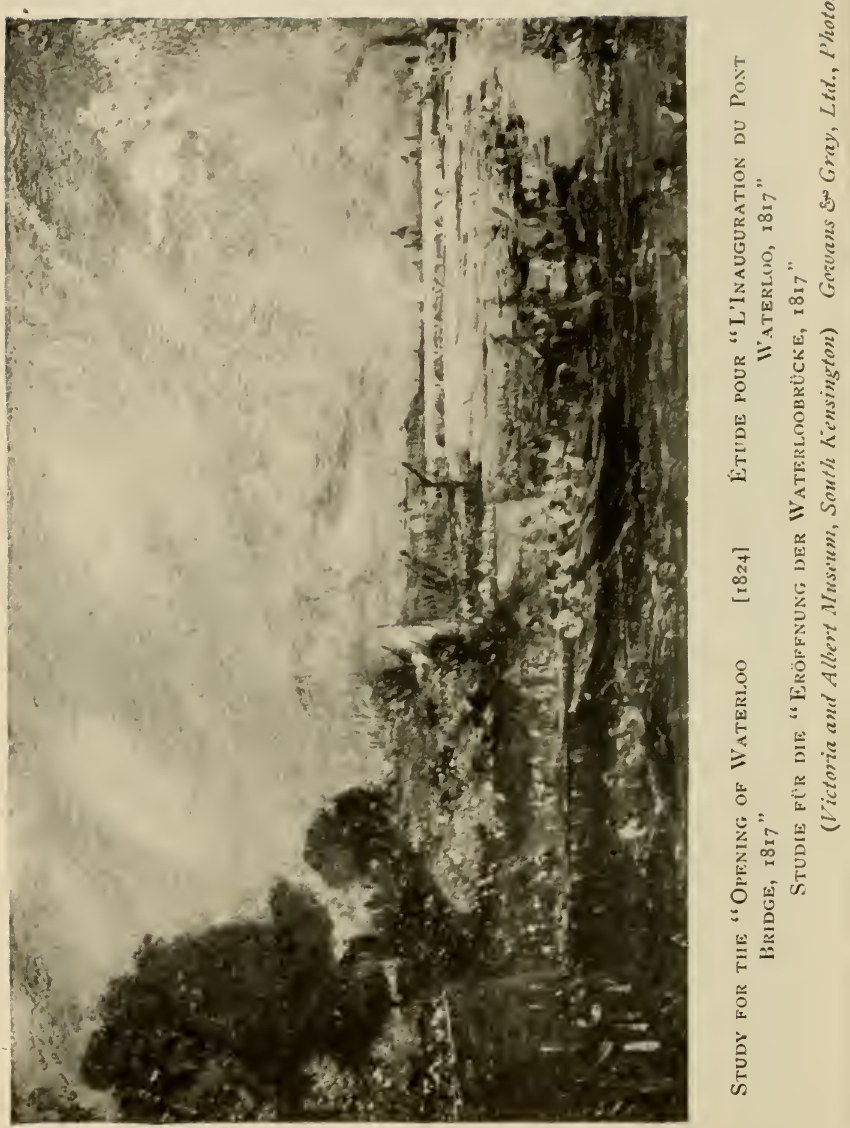


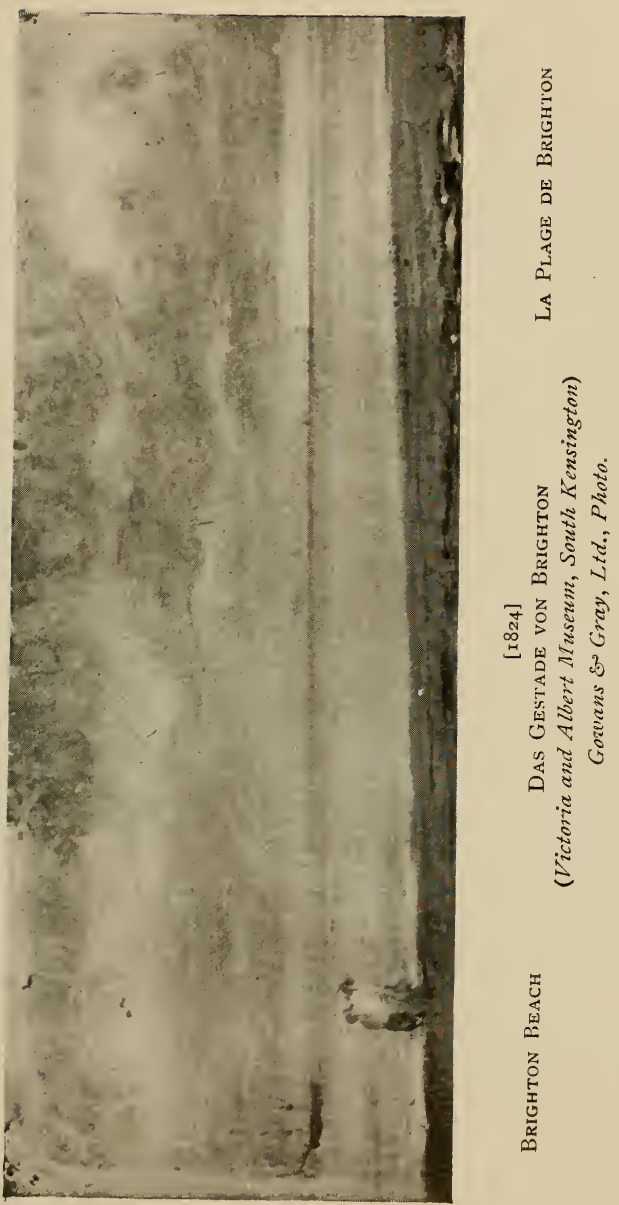




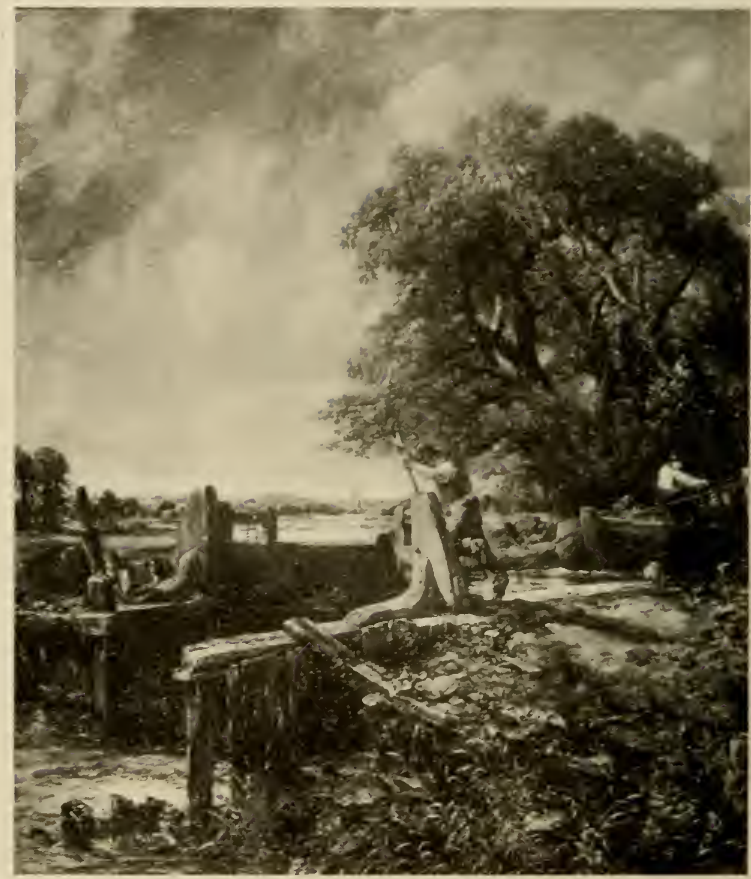

$$
\text { [1824] }
$$

The Lnck Die Schleuse

L'Écluse

(The late MIr. Jas. Morrison, Basildon Park) W. A. Mansell \& Co., Photo. 


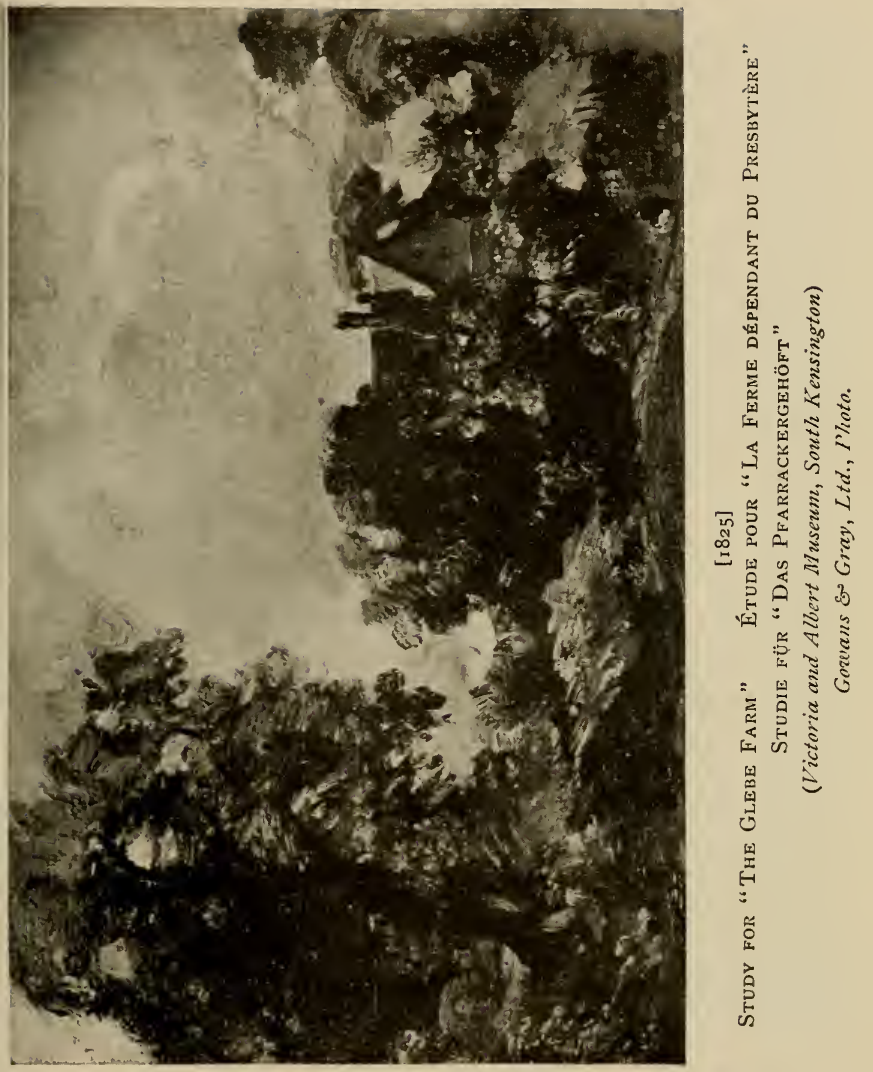




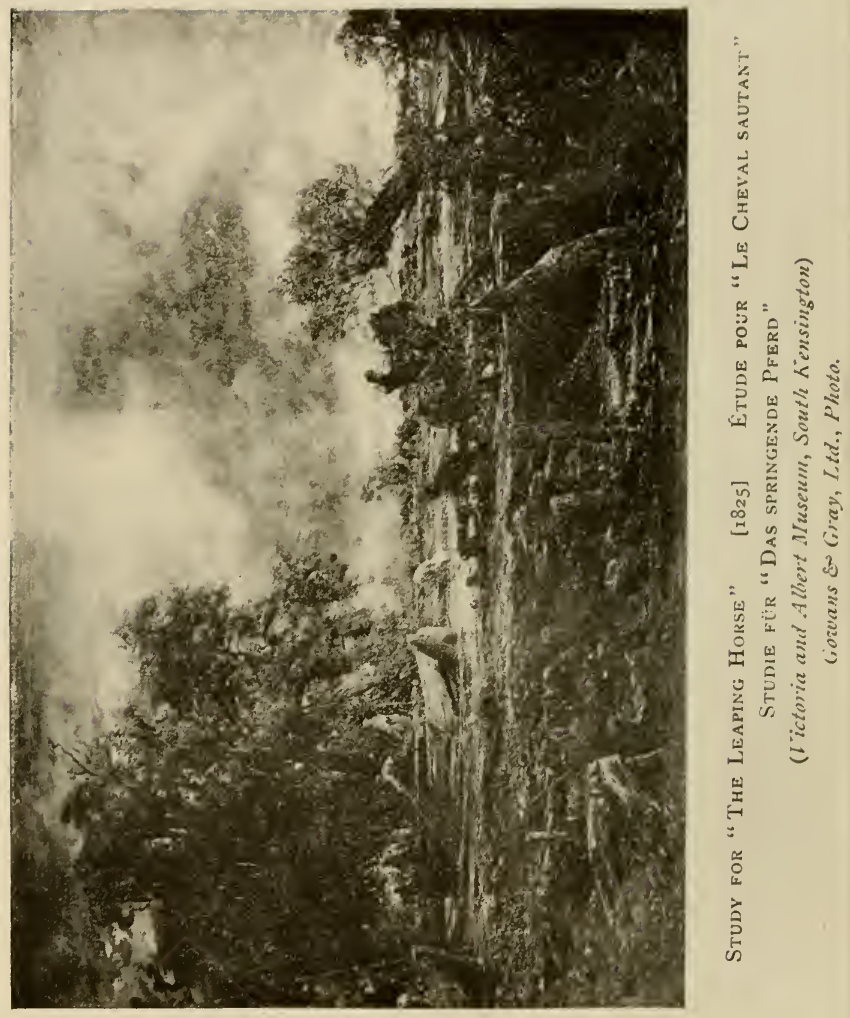




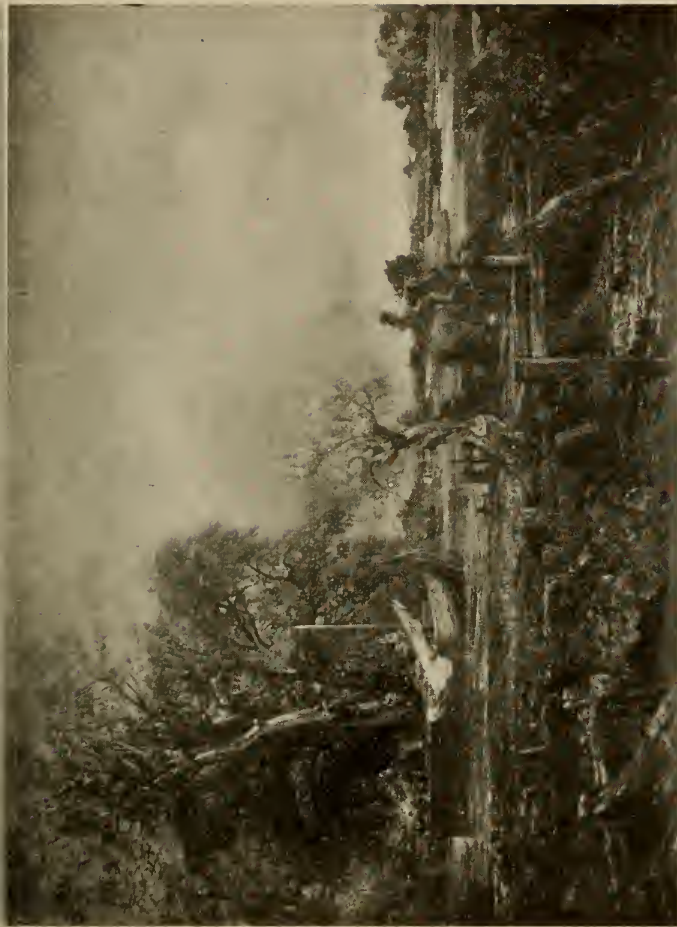

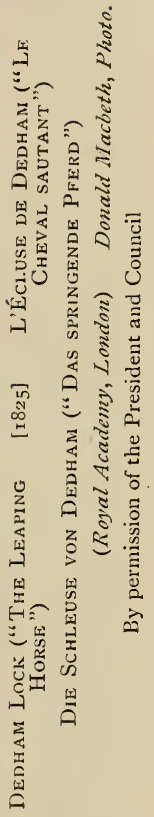



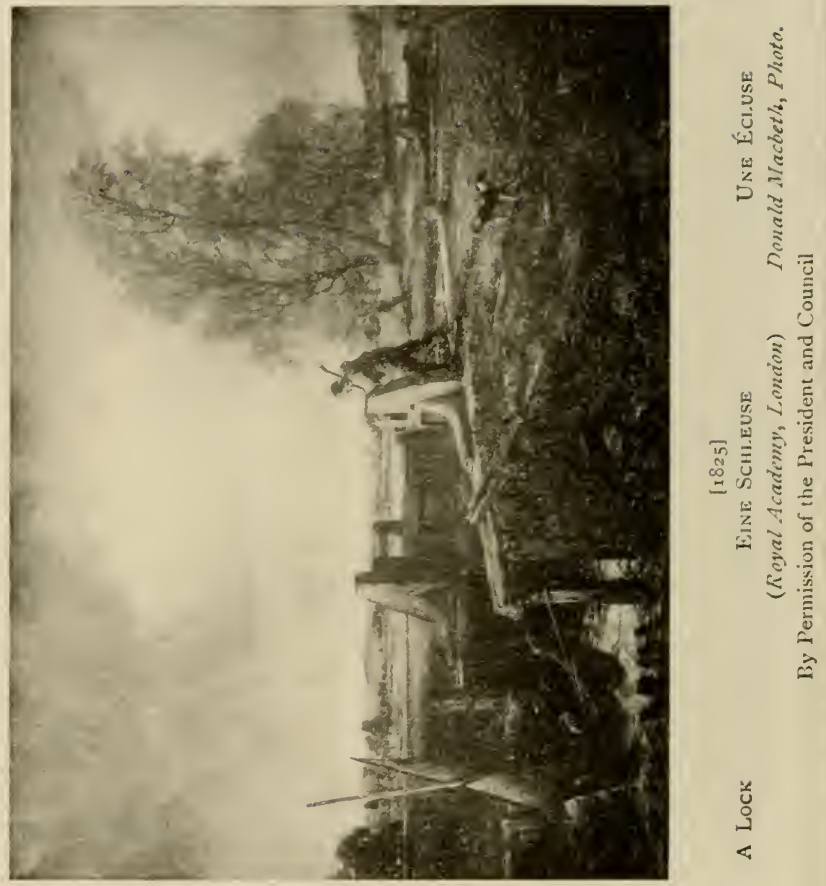


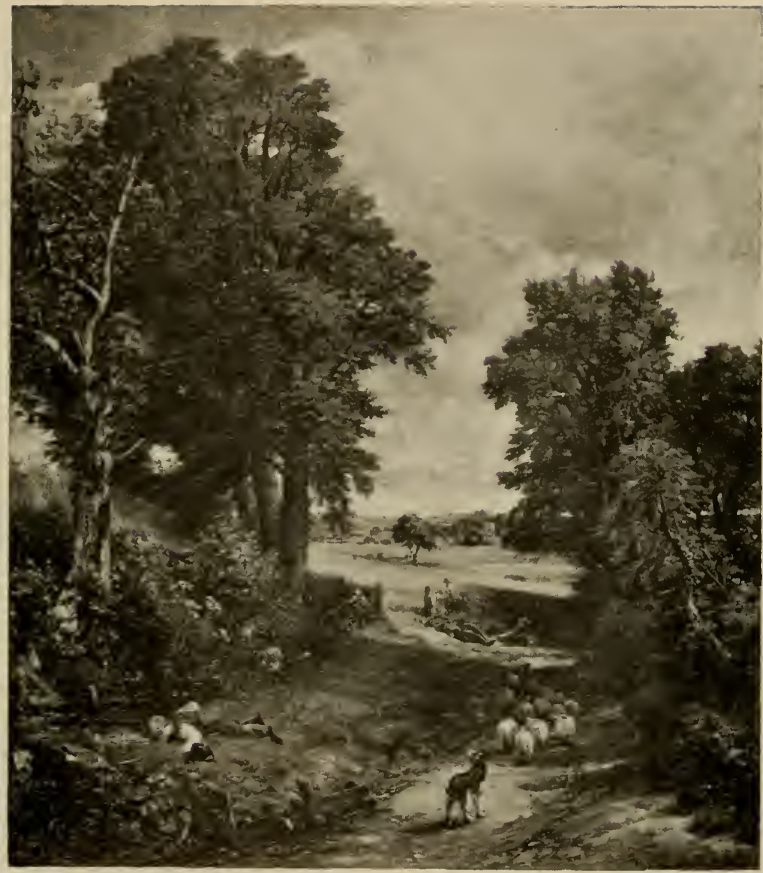

The Cornfield (National Gallery, London)
[1826]

Le. Champ de Blé

(Galerie nationale, Londres)

DAS KoRnFELD

(London, Nationalgalerie)

F. Hanfstaengl, Photo. 


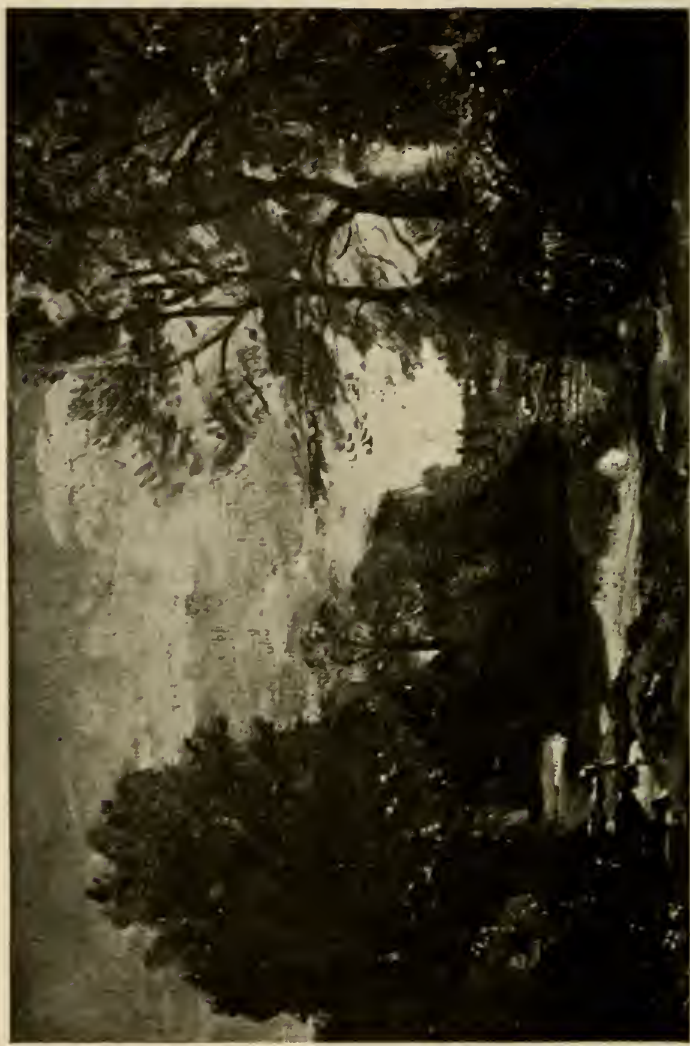

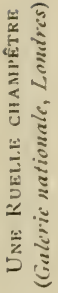

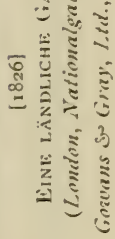

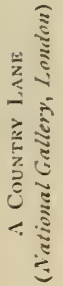




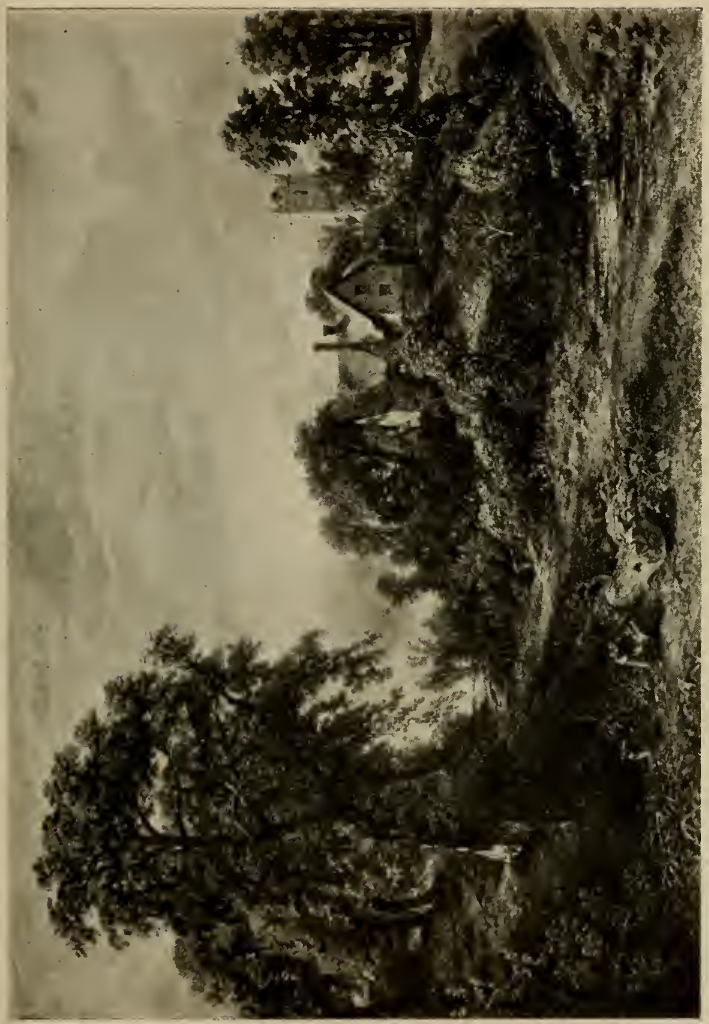

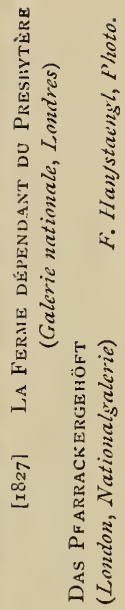

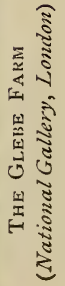



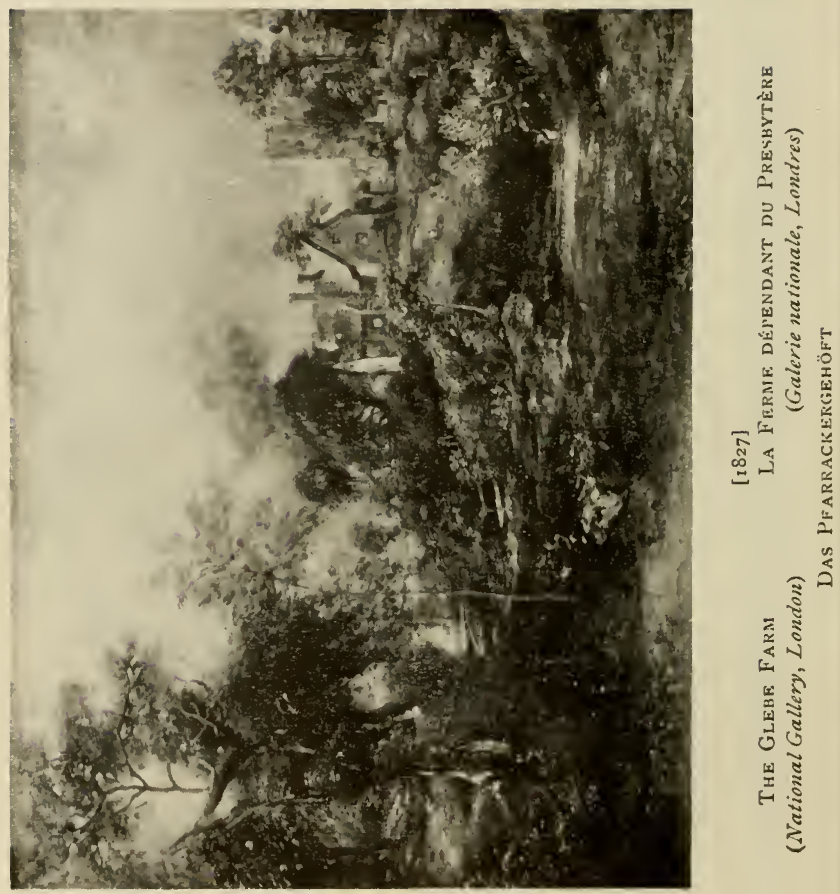

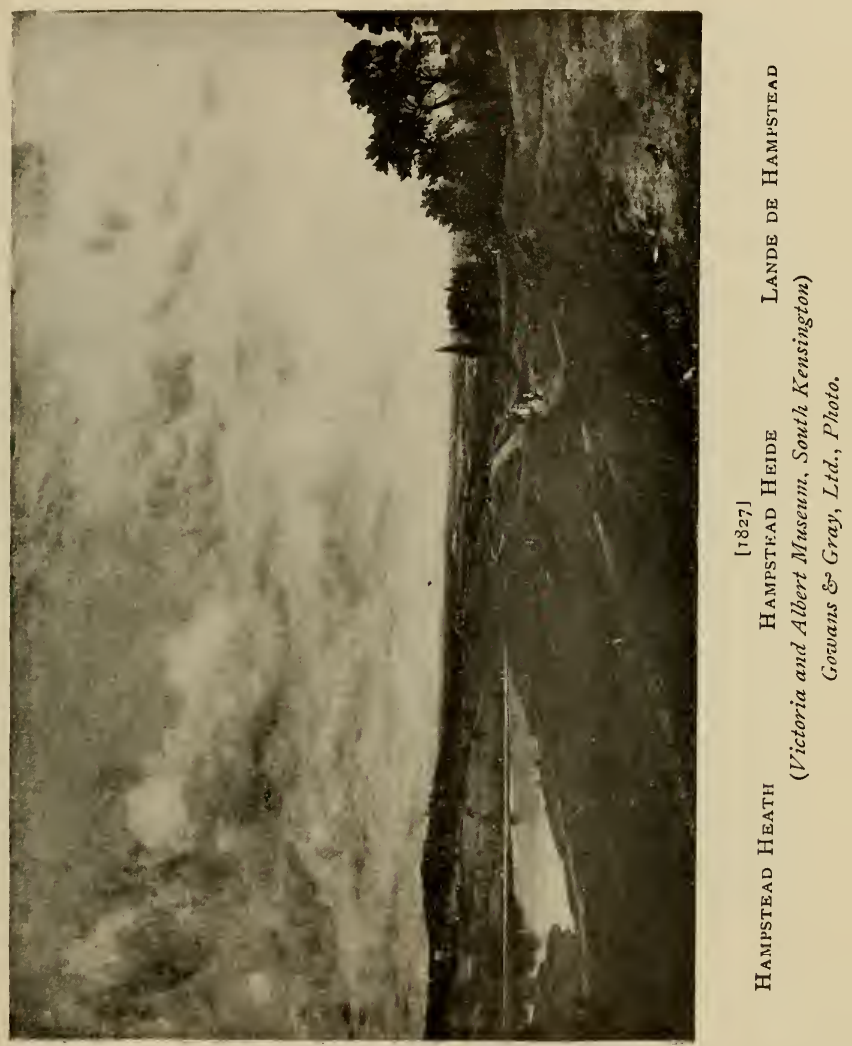


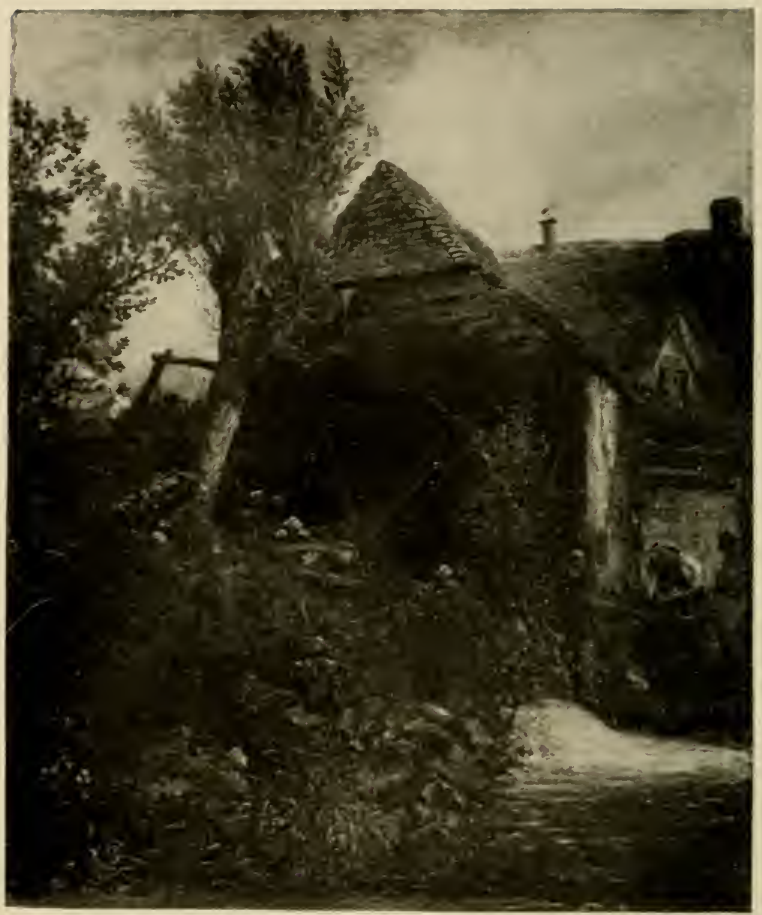

[ 1827 ]

Watfrilll at Gillingham Moulin a Eau a Gillingiam

WASSERMínI.E ZU GiLlinguaM

(Victoria and Albert Museum, South Kensington)

Gowans \& Gray, Ltd., Photo, 

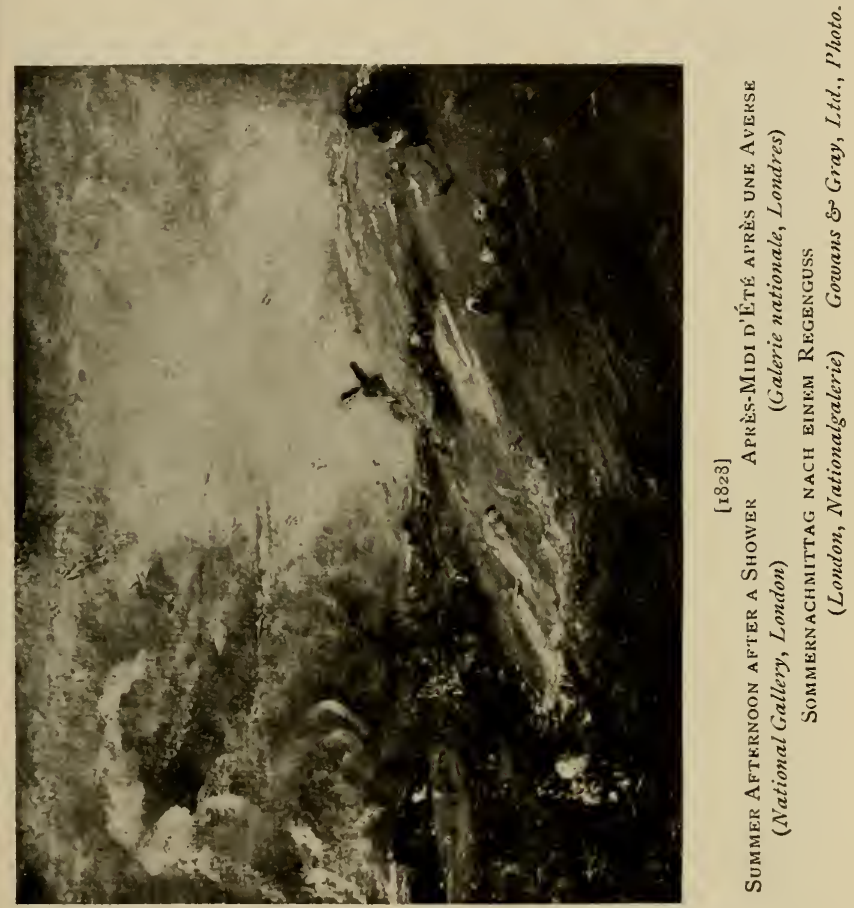


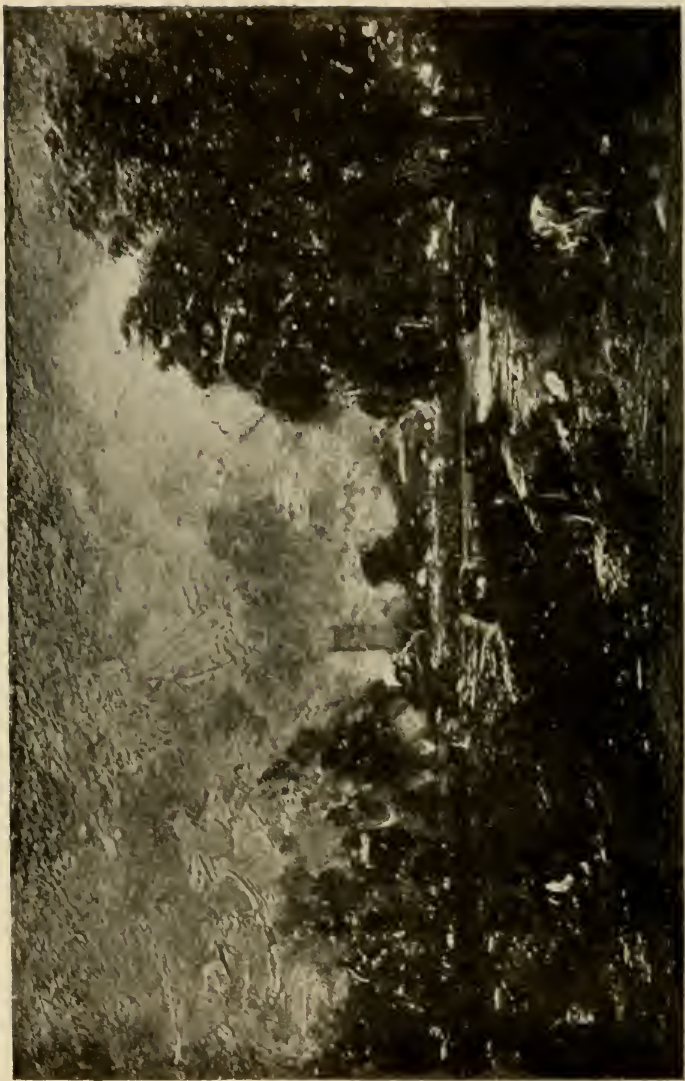



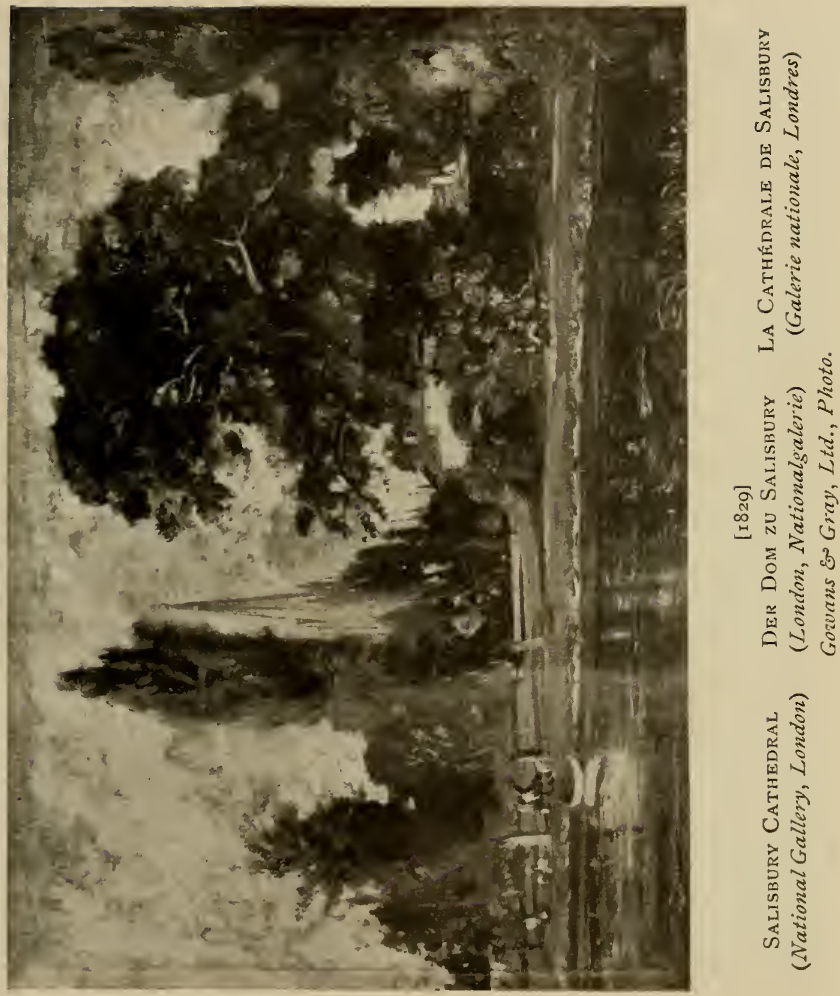


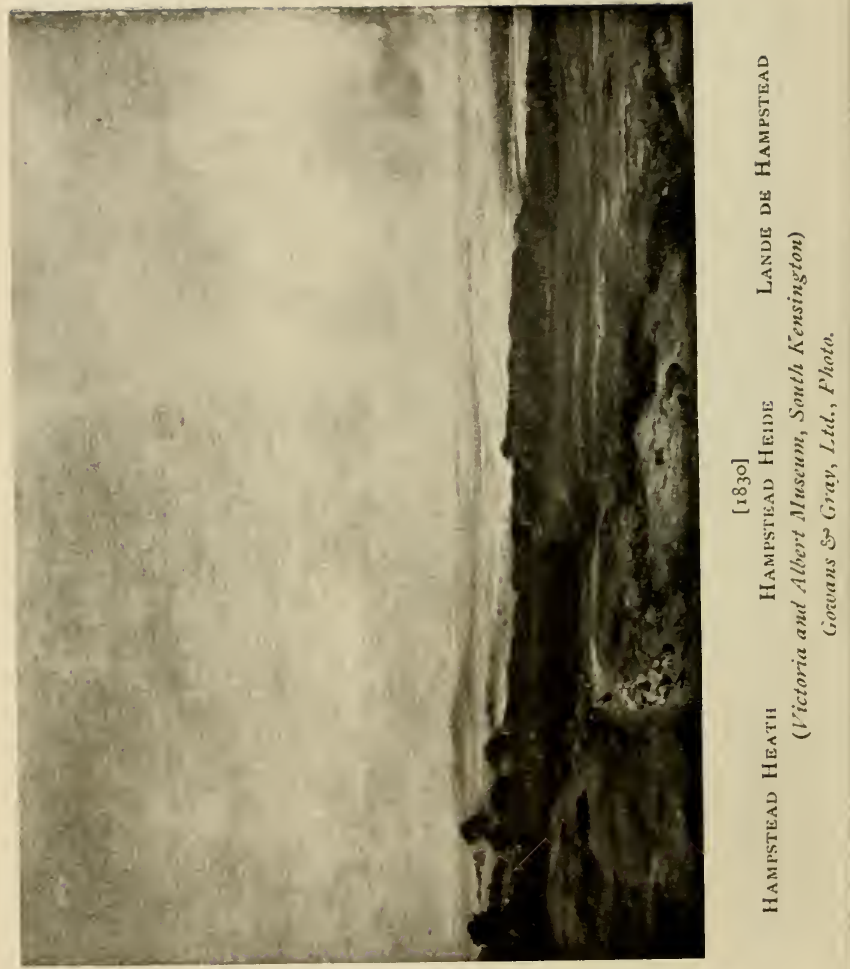



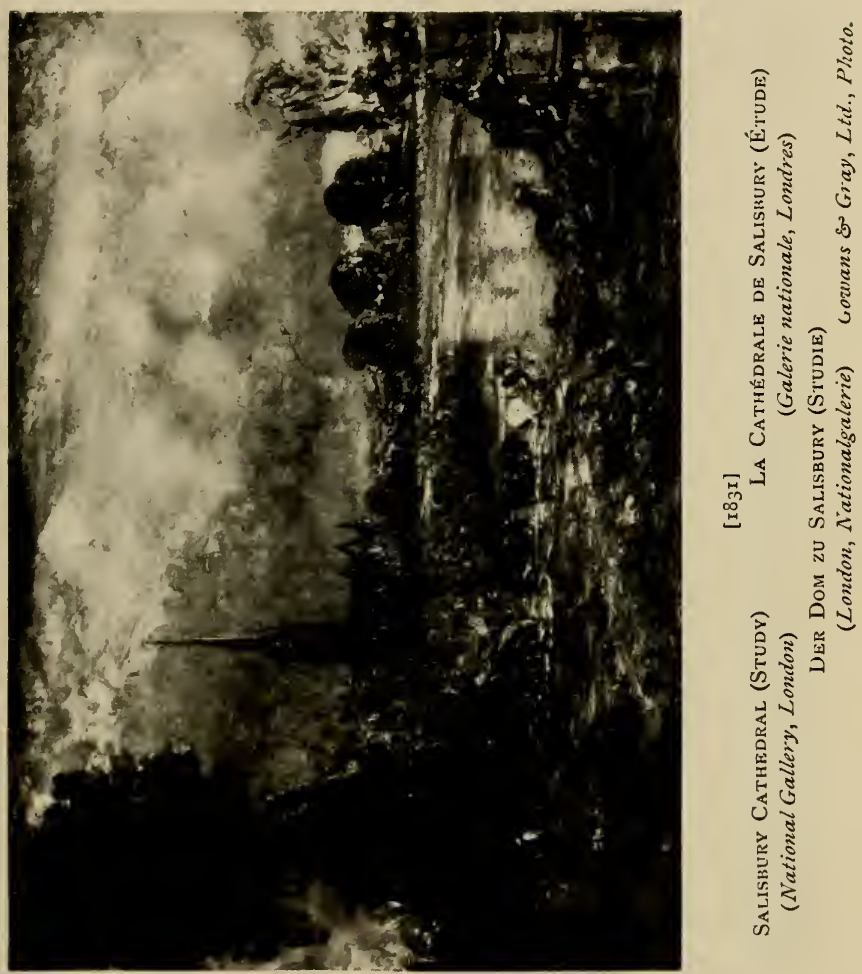


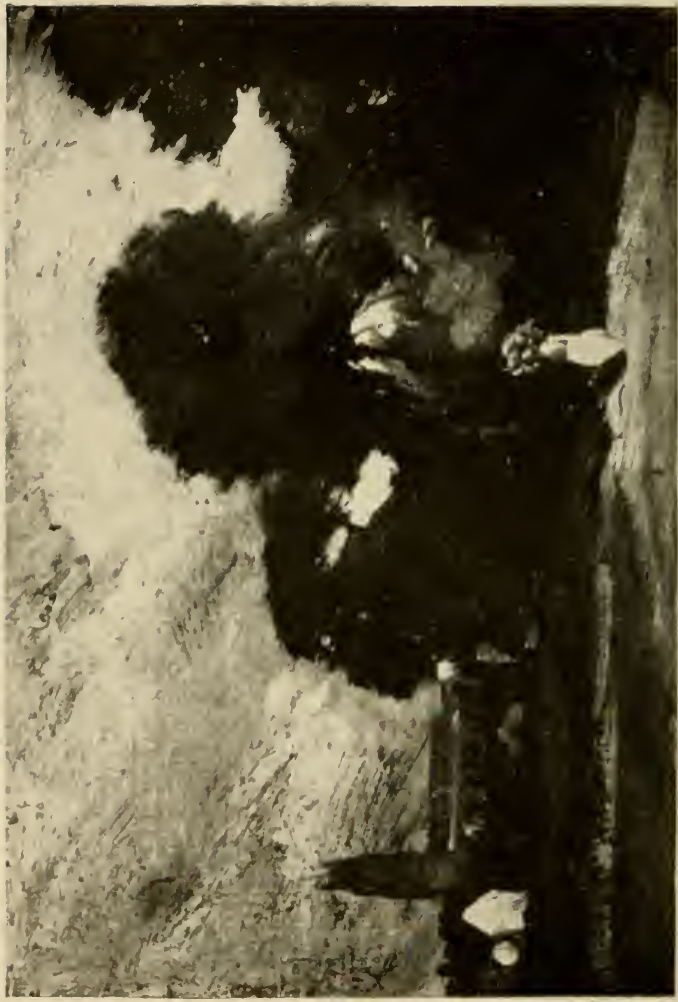

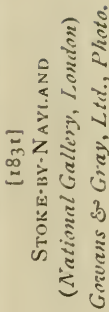




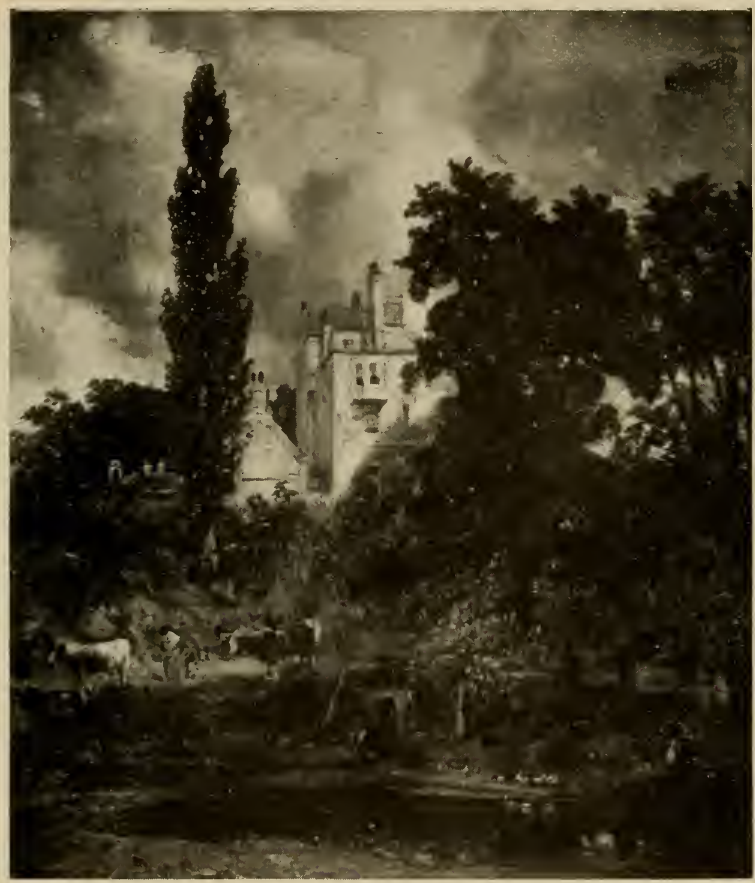

A Romantic House, [1832] Une Maison romantique, HAMISTEAD HAMPSTEAD

(National Gallery, London) (Galerie nationale, Londres)

Ein Romantisches Haus, Hampstead

(London, Nationalgaleric)

Gowans \& iray, Ltd., Photo. 


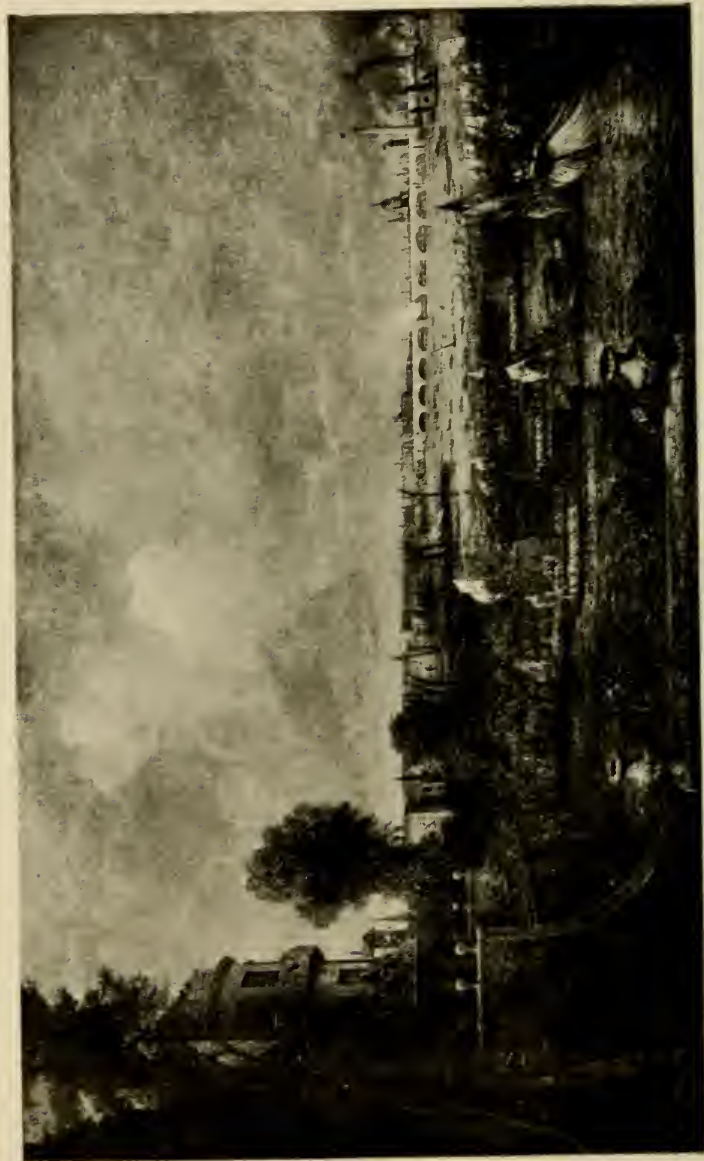

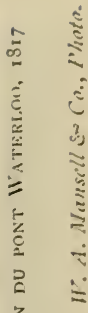

品

क

E

z

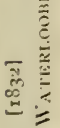

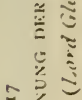

क :

然



0
$\frac{0}{3}$
$\frac{2}{2}$
$\frac{2}{2}$
$\frac{2}{2}$
$\frac{2}{2}$ 


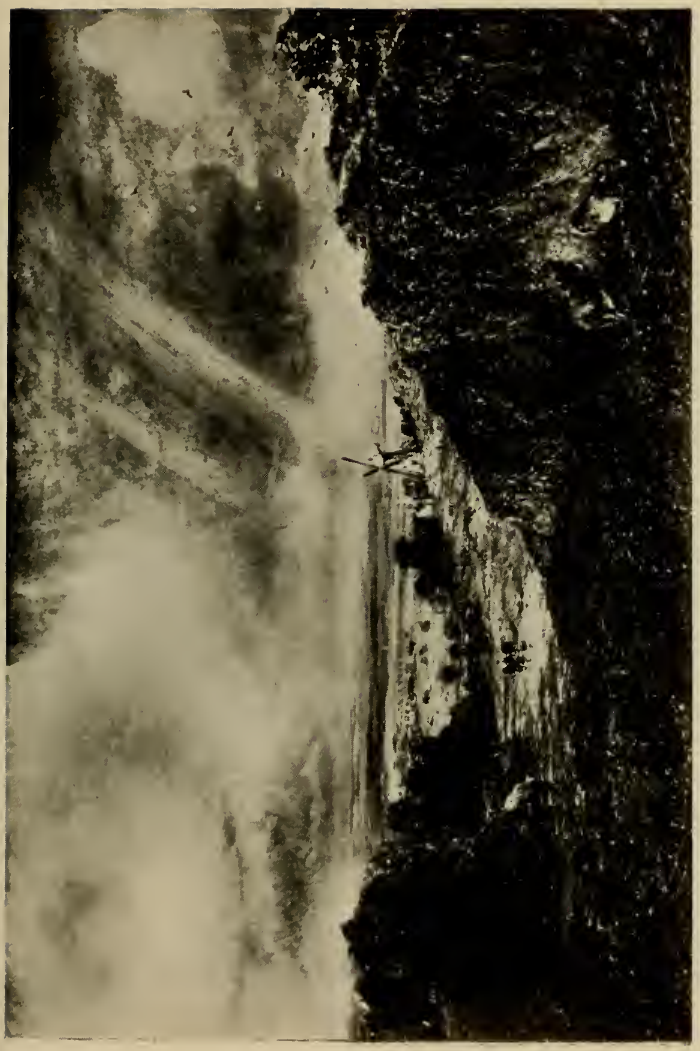

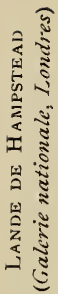

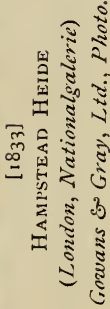

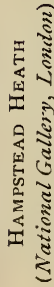




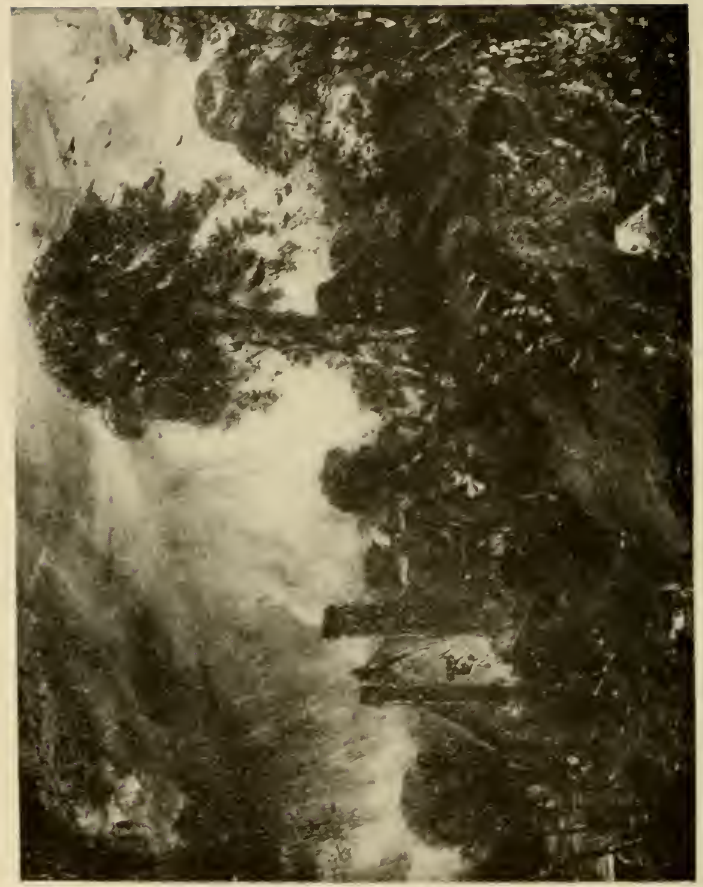




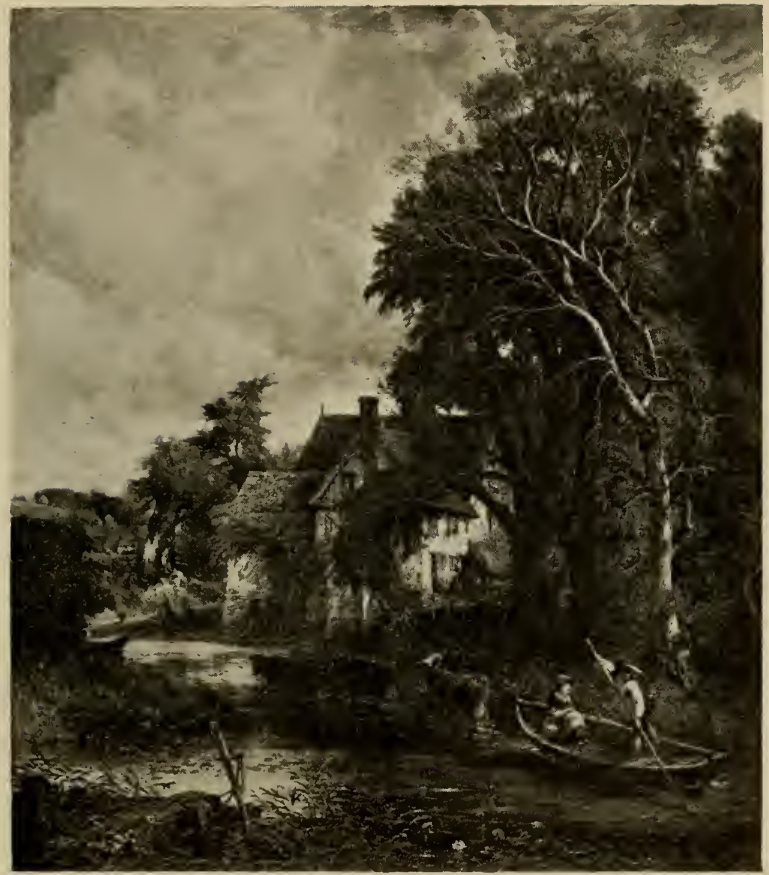

[1835]

TuE Valley Farm (National Gallery, London)
La Ferme dans i.a Vallé (Galerie nationale, Londres)

\section{DAS TALGEHÖFT}

(London, Nationalgalerie)

F. Hanfstaengl, Photo, 


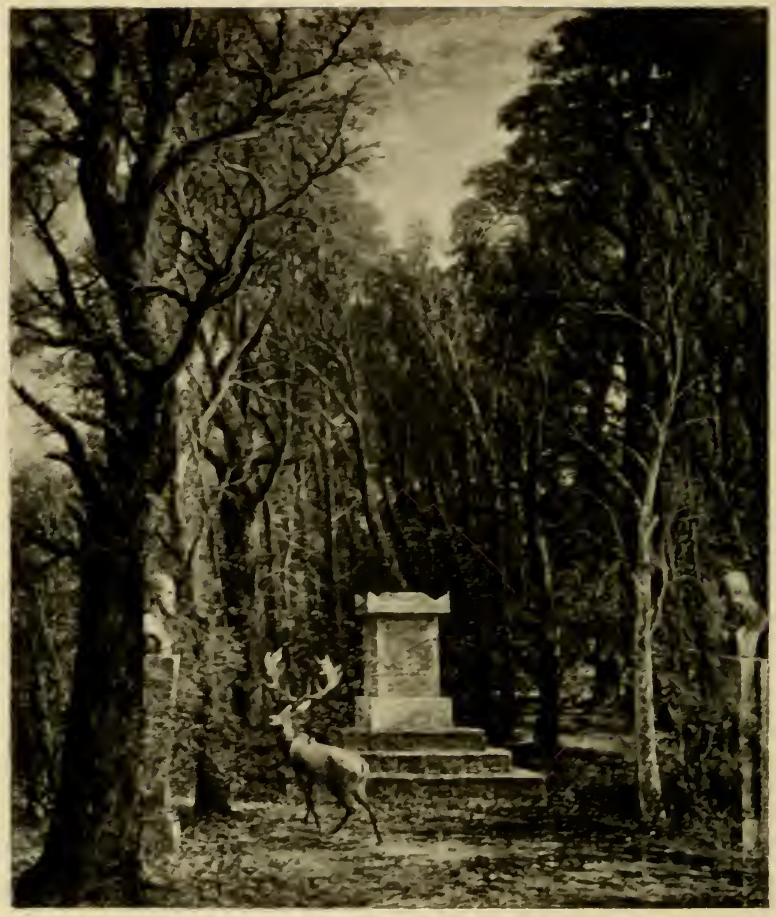

Tine Cenotain

(. Vational Gallery, Loulon)
$[1835]$

UAS EHRENGRA UMAL.

(London, Mationalgalerie)

F. Ilanfstaengl, Photo.
J.e Cenotaphe

(Galerie nationale, Londres) 
A Complete List of Published Photographs ot

\section{CONSTABLE'S PICTURES}

to be had of Mr. Franz Hanfstaengl,

I 4 Fifth Avenue, New Tork.

SIZES AND PRICES oF PHOTOGRAPHS-

$\mathrm{F}=$ Folio, $7 \times 10$ (with Mount, $15 \times 20$ ) Carbon Print, $\$ 1.50$

R=Royal, $11 \times 15$ (with Mount, $23 \times 29$ ) , $\quad 3.00$

I=Imperial, I $6 \times 2$ I (with Mount, $29 \times 36) \quad$ ", 5.00

Facs $=$ Facsimile, $20 \times 28($ with Mount, $29 \times 40), \quad 12.00$

$\mathrm{E}=$ Extra, $25 \times 35$ (with Mount, $36 \times 47$ ) ", $\quad 18.00$

Average Dimensions are quoted.

In ordering it is essential that both Gallery and Order Number

are stated as well as the Size.

\begin{tabular}{|c|c|c|c|}
\hline Thtux. & GaLLERT. & No. & S1zk. \\
\hline $\begin{array}{l}\text { Hampstead Heath, } \\
\text { The Hay Wain, } \\
\text { Flatford Mill with river Stour. : } \\
\text { lhe C rnfield, } \\
\text { The Valley Farm, - } \\
\text { The Cenotaph, } \\
\text { The Glebe Farm, - } \\
\text { Bay of Weymouth at tho approach } \\
\text { of a Storm, }\end{array}$ & $\begin{array}{l}\text { Glasgow } \\
\text { Londou, N.G. } \\
\text { ", } \\
\text { ", } \\
\text { ", } \\
\text { Lourre }\end{array}$ & $\begin{array}{r}35 \\
1 \\
2 \\
56 \\
57 \\
58 \\
170\end{array}$ & 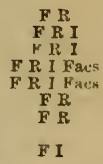 \\
\hline
\end{tabular}




\section{“THE “PAINTERS” SERIES}

THis Series, published at a very low price and containing in each volume SIXTY beautifully-printed reproductions of the best pictures of the great masters, is intended to give the lover of art a general idea of the style and characteristics of the most famous painters of the world.

Ready.

I. RUBENS

2. VAN DYCK

3. REMBRANDT

4. RAPHAEL

5. REYNOLDS

6. TENIERS

7. EARLY FLEMISH PAINTERS

8. TITIAN

9. FRANS HALS

10. MURILLO

11. WOUWERMAN

12. VELAZQUEZ

13. HOLBEIN

14. VERONESE

15. RAEBURN

16. DEL SARTO

17. CORREGGIO

18. BRONZINO

19. WATTEAU

20. BOTTICELLI

21. FRA ANGELICO
22. TINTORETTO

23. POUSSIN

24. PERUGINO

25. MICHELANGELO

26. GOYA

27. DÜRER

28. GAINSBOROUGH

29. LOTTO

30. LUINI

31. GREUZE

32. CARPACCIO AND GIORGIONE

33. HOGARTH

34. GIOTTO

35. MORETTO

36. ROMNEY

37. ORCAGNA, Etc.

38. GERARD DOU

39. BOUCHER

40. CONSTABLE

41. MASACCIO, Etc.

42. JAN STEEN

Others in Preparation. Price in Parchment Covers, 25 Cents.

FREUK. A. STUKes CO., New York, Publishers. 



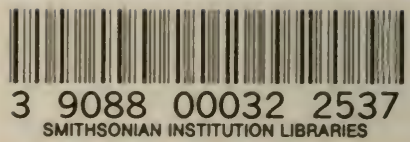

